ANADOLU, J. of AARI

ISSN: $1300-0225$ (Print)

E-ISSN: 2667-6087 (Online)

2021, 31 (2): 226-244

DOI: $10.18615 /$ anadolu. 1033609

\title{
İmir İlinde Bulunan Nadir, Endemik ve Tehdit Altındaki Bitki Türlerinin Toplanması ve Ex Situ Muhafazası
}

\author{
Erdinç $\boldsymbol{O} \breve{G} U R^{*}$
}

*Ege Tarımsal Araştırma Enstitüsü Müdürlüğü, Menemen, İzmir/ TURKEY

${ }^{*}$ https://orcid.org/0000-0002-4496-2995

*Corresponding author (Sorumlu yazar): erdinc.ogur@tarimorman.gov.tr

Received (Geliş tarihi): 24.05.2021Ａccepted (Kabul tarihi): 23.08.2021

\begin{abstract}
ÖZ: Endemik ve nadir bitkiler bir ülkenin bitkisel genetik kaynak zenginliklerinin bașında gelmektedir. Ülkenin sahip olduğu zengin genetik kaynaklar ekonomik, sosyal ve kültürel değerleri nedeniyle stratejik bir öneme sahiptir. Bitki genetik kaynaklarımızın korunması, mevcut ve gelecek nesiller için sürdürülebilir kullanımının sağlanarak ekonomik değere dönüşü̈rülmesi ülkemiz için büyük önem taşımaktadır. Bu çalışma, İzmir ilinde bulunan endemik, nadir ve tehdit altındaki bitki türlerinin toplanması ve ex situ muhafazası amacıyla 2014-2018 yılları arasında gerçekleştirilmiştir. Yapılan arazi çalışmaları sonucunda toplanan örneklerin 188 tanesinin çalışmada hedeflenen taksonlar olduğu belirlenmiştir. Bu türlerden 115 tanesi endemik, 48 tanesi tip örneği Türkiye olan, 13 tanesi nadir ve 12 tanesi endemik ya da nadir olmayıp IUCN kriterlerine göre tehdit kategorisinde olan taksonlardır. Yapılan arazi çalışmaları sonucunda tespit edilen taksonların IUCN tehdit kriterlerine göre tehlike kategorileri de belirlenmiştir. Bu taksonlardan bir takson Doğada Tükenmiş (EW), 6 takson Kritik (CR), 19 takson Tehlikede (EN), 36 takson Duyarlı (VU), 9 takson Korumaya Tabi (CD), 50 takson Düşük Riskli (LC), 14 takson Tehdite Yakın (NT) ve 3 takson Veri Yetersiz (DD) kategorisindedir. Hedef türlerin 188'inin herbaryum örnekleri alınırken 75 'inden tohum materyali alınmıştır. Toplanan herbaryum örnekleri ETAE Herbaryumunda (IZ), tohum materyali ETAE Ulusal Tohum Gen Bankasında muhafazaya alınmıştır. Bu çalışmanın sonuçları, endemik ve nadir bitkilerimizin iyi tanınması, korunması ve çoğaltılarak ekonomiye kazandırılması açısından önemlidir.
\end{abstract}

Anahtar Kelimeler: İzmir, nadir ve endemik bitkiler, ex situ koruma, herbaryum örneği, tohum gen bankası.

\section{Collection and Ex Situ Conservation of Rare, Endemic and Threatened Plant Species in İmir Province}

ABSTRACT: Endemic and rare plants are at the foremost of a country's plant genetic resource richness. The rich genetic resources of the country have a strategic importance due to their economic, social and cultural values. It is of great importance for Turkey to protect plant genetic resources and to transform them into economic value by ensuring their sustainable use for current and future generations. This study was carried out between 2014-2018 for the collection and ex situ conservation of endemic, rare and endangered plant species in İmir Province. As a result of the field studies, it was determined that 188 of the collected specimens were the target species taxa of the study. Overall, 115 out of 188 specimens are endemic, 48 are type samples which are only found in Turkey, 13 are rare and 12 are neither endemic nor rare but categorized as endangered according to IUCN criteria. The conservation status of the taxa found as a result of the field studies were also determined according to IUCN criteria. Among these taxa 1 is in the Extinct in the Wild (EW) category, 6 are in the Critically (CR), 19 are in the Endangered (EN), 36 are in the Vulnerable (VU), 9 are in the Conservation Dependent (CD), 50 are in the Least Concern $(L C), 14$ are in the Near Threatened (NT) and 3 are in the Data Deficient (DD) categories. While herbarium specimens were taken from 188 of the target species, seed material was taken from 75 of them. The collected herbarium samples were kept at the AARI Herbarium (IZ) and the seed material were kept National Seed Gene Bank at AARI. The results of this study are important allowing for our endemic and rare plants to be well known, protected, and reproduced and to contribute to the economy.

Keywords: Izmir, rare and endemic plants, ex situ conservation, herbarium specimens, seed gene bank. 


\section{GíRIŞ}

İnsanoğlunun başta gıda olmak üzere temel ihtiyaçlarının karşılamasında vazgeçilmez bir yeri olan canlı kaynakların temeli, biyolojik çeşitliliktir. Biyoçeşitlilik, genetik farklılıklara sahip canlı türlerinden oluşan, değişik işlevlere sahip çeşitli ekosistemlere dağılmış olan sayı ve tür bakımından zengin canlılar toplumunun oluşturduğu yaşam alanlarıdır (Çepel, 2003).

Türkiye, canlı türleri ve genetik özellikleri ile ekosistemlerin çeşitliliği bakımından oldukça zengin bir ülkedir. Bunun başlica sebepleri kıtalar arasında yer alması, çok kisa mesafelerde son derece farklı yeryüzü şekillerine sahip olması ve klimatolojik bakımdan dünyanın en hareketli bölgelerinden biri olmasıdır. Bütün bu etkenlere ek olarak göçler ve antropolojik etkiler de Anadolu'daki biyolojik çeşitliliği büyük oranda artırmıştır (Demirsoy, 1996). Ülkemizden çok daha büyük yüz ölçümüne sahip Avrupa kıtasında 12.000 civarında bitki türü tespit edilmiş ve bunlardan 2.750 civarında taksonun endemik olduğu belirtilmiştir (Heywood and Tutin, 19631980). Türk bilim insanlarının Türkiye Florasını yeniden yazmaya başlamasıyla beraber Türkiye Bitkileri Listesi kitabı (Güner ve ark., 2012) ile ülkemiz florasına ait damarlı bitkiler derlenmiştir. $\mathrm{Bu}$ verilere göre Türkiye Florasında 167 familyaya ait 1.321 cins, 10.036 tür ve 11.707 damarlı bitki taksonu (alttür, varyete, hibrid) bulunmaktadır ve bu taksonların 3.649'u $(\% 31,82)$ endemiktir (Güner ve ark., 2012).

Ülkemizin, biyoçeşitlilik açışından küçük asya olarak tanımlanmasının önde gelen nedenleri aşağıda belirtilmiştir (Karagöz ve ark., 2010; Tan, 2010a; Tan, 2010b):

- İklim ve toprak açısından farklı niteliklere sahip yöreler - farklı ekosistemler bulundurması

- Farklı jeolojik tabakaların ve coğrafik oluşumların yer alması

- Deniz seviseyinden başlayarak 5.000 metreye kadar yükselti farklılığının bulunması

- Ülkemizin, dünyada bulunan 8 bitki gen merkezinden ikisinin (Yakındoğu ve Akdeniz Gen Merkezlerinin) çakıştı̆̆ bölgede bulunması
- Türkiye'de 3 bitki coğrafya bölgesinin (Avrupa-Sibirya, Akdeniz ve İran-Turan Bitki Coğrafya Bölgeleri) buluşması. (Dünya, bitki coğrafyası bakımından 37 fitocoğrafik bölgeye ayrilmaktadır.)

- Büyük buzul dönemlerinde Avrupa kıtasının çoğunun donmasına karşıllk Anadolu'nun mikroklima alanları sayesinde birçok canlıya sığınak olması

- Dünyada tarımın ilk yapıldığı yörenin ülkemizde bulunması (Göbeklitepe)

- Dünyada yüksek derecede bitki endemizmi bulunduran önemli ülkelerden biri olması,

- Kültüre alınan pek çok bitki türünün makro ve mikro gen merkezi olmasi.

Tarihsel süreç içerisinde İzmir ilinde yapılan floristik araştırmalara bakıldığında oldukça kapsamlı çalışmaların yapılmış olduğu görülmektedir. $\mathrm{Bu}$ çalışmaların en önemli olanların başında 'Flora Orientalis'i yazan ünlü botanikçi Pierre Edmond Boissier (1810-1885)'in çalışmaları gelir. Boisser, İzmir ilinde bulunan Nif Dağı ve Bozdağ'da yaptığ araştırmalar sonucunda birçoğu lokal endemik olan yeni bitki türünü bilim dünyasına tanıtmıştır. Boisser'in tanımladığ 1 önemli bitkiler arasında Rumex tmoleus, Astragalus tmoleus, Linum tmoleum, Stachys tmolea, Linum aretoides, Scilla luciliae, Astragalus lydius, Centaurea lydia, Verbascum lydium, Salvia smyrnaea, Ornithogalum nivale, Bromus macrocladus gibi bitkiler yer alır. İzmir sınırları içinde önemli çalışmalar yapan diğer bir araştırıcı ise 1931-1934 yılları arasında İzmir Zirai Mücadele Araştırma Enstitüsünde çalışmış olan Otto Schwarz'dir. Schwarz Antemis xylopoda, Asperula daphneola ve Potentilla subleavis gibi İzmir'den başka yerde olmayan nokta endemikleri bilim dünyasına tanıtmıştır (Anonymous, 2018a).

Ülkemizin iklim, jeoloji ve coğrafi yapısının farklılığı, genetik çeşitliliği artırırken aynı zamanda yüksek endemizm sağlar. Türkiye, birçok bitkinin makro ve mikro gen merkezidir ayn zamanda endemik bitki türleri ve sayısı bakımından dünyanın önemli ülkeleri arasında yer alır (Karagöz ve ark., 2010).

Dünyada varolan tüm bitki türlerinin, özellikle lokal endemiklerin yok olmadan korunmaları için 
son süreçte önemli çalışmalar yapılmaktadır. Endemik bitkilerin korunmasında öncelik, antropojenik bask1 altında olan ve nesli kaybolma tehdidi altında (CR, EN, VU) olanlara verilmektedir. $\mathrm{Bu}$ amaçla uluslararası kuruluşların yanısıra, tüm ülkeler kendi bitkilerini korumak amaciyla çalışmalar yürütmektedirler. Ülkemizde de bu amaçla bilim insanlarımız çalışmalar yaparak tehdit altındaki bitki türlerinin listesi ve tehdit kategorileri belirlemişlerdir. Daha sonra Nezahat Gökyiğit Botanik Bahçesi ve Ali Nihat Gökyiğit Vakfi (ANG Vakfi) tarafindan Tehdit Altında Bitki Türlerinin Listesi hazırlanmıştır. Buna göre Ülkemizde 2221 tür tehlike altındadır (Anonymous, 2018b).

İzmir, doğal güzelliğinin yanı sıra tarihi dokusu ve antik kentleri ile tanınmıştır (Tezer, 2012). Aynı zamanda farklı iklimsel özellikleri jeolojik ve jeomorfolojik oluşumları, kendine has toprak ve kaya yapısı ve sulak alanlarıyla birçok endemik ve nadir bitkiye ev sahipliği yapmaktadır. İnsanlık tarihi ile beraber gelişen yerleşim alanları ve antik kentlerinde çok değerli lokal endemik bitkiler bulunmaktadır.

İzmir'de yetişen endemik, nadir ve endemik olmayan bitkiler çeşitli baskılar altında olup, bir kısmı bu olaylar sonucu neslini devam ettirebilmekte zorluklarla karşılaşmaktadır. Özellikle nüfus artışına parelel olarak şehirleşme ve sanayileşmenin olumsuz etkileri bazı dar yayılıșlı bitkiler üzerinde tehlike yaratmaktadır. Endemik bitkiler bir ülkenin biyolojik zenginliklerinin başında gelmektedir. $\mathrm{Bu}$ bakımından endemik bitkilerin iyi tanınarak yok olma tehdidine karşı koruma önlemlerinin alınması bu türlerin nesillerinin devamı için çok önemlidir. Bölgedeki nesli tehlike altında olan bitki türlerinin, acilen tespit edilip ex-situ ve in-situ muhafaza olanakları araştırılarak korunmaları, genetik kaynaklar ve çeşitlilik açısından büyük önem taşımaktadır.

Yukarıda belirtilen sebeplerden dolayı endemik bitkilerin populasyonlarında azalmalar olduğu ve bu azalmaların gittikçe arttığı bilinmektedir. Yapılan bilimsel çalışmalar incelendiğinde İzmir'de yapılan çalışmaların daha çok floristik araştırmalarla sınırlı kaldığı görülmektedir. $\mathrm{Bu}$ nedenlerle çalışmamızın temel amacı, İzmir ve çevresindeki nadir, endemik ve tehdit altındaki bitki türlerinin tespit edilmesi ve ex-situ muhafazaya alınarak biyolojik çeșitliliğin korunması olarak belirlenmiştir.

\section{MATERYAL ve METOT}

$\mathrm{Bu}$ çalışmanın materyalini, İzmir iline ait endemik ve nadir bitkiler ile endemik olmamasına rağmen IUCN (Uluslararası Doğa Koruma Birliği)'e göre tehlike kategorisinde olduğu bildirilen bitki taksonlarının herbaryum ve tohum örnekleri oluşturmaktadır. Çalışma materyali olan endemik ve nadir bitkilerinin belirlenmesinde öncelikle Türkiye Florası ve Türkiye Bitkileri Veri Servisi (TÜBİVES) (Anonim, 2011), tehdit altındaki bitki taksonların kategorilerinin belirlenmesinde Türkiye Kırmızı Bitkiler Kitabı (Ekim ve ark, 2000) verileri esas alınmıştır.

Hedef türler listesi hazırlanırken aşağıdaki kaynaklar da kullanılmıştır;

- Taksonların endemizm durumu ve Türkçe isimleri için ülkemizdeki en kapsamlı kontrol listesi olan Türkiye Bitkileri Listesi (Damarlı Bitkiler) kitabı (Güner ve ark., 2012).

- Tüm dünyada geçerli kabul edilen isimler Türkiye Bitkileri Listesi 'den kontrol edilerek yazılmıştır. Ayrıca "The Plant List" (Anonymous, 2013a) ve "International Plant Names Index" (Anonymous, 2018c) web adreslerinden de yararlanılmıştır.

- Tehdit kategorileri için www. tehditaltındabitkiler.org.tr adresi (Anonymous, 2018b), "International Union for Conservation of Nature" tehlike kategorileri (Anonymous, 2001; 2003) ve "The Convention on International Trade in Endangered Species of Wild Fauna and Flora" (Anonymous, 2009).

- Türkiye Florası'ndan sonra çıkan yeni tür, yenikayıt, yeni lokalite gibi verilere ulaşmak için diğer kontrol listeleri (Özhatay ve ark., 2013; Özhatay ve ark., 2015; Özhatay ve ark., 2017)

- Türkiye'nin Önemli Bitki Alanları (Özhatay ve Kültür, 2006), Türkiye'nin Önemli Doğa Alanları (Eken ve ark., 2006) eserleri. 


\section{Araştırma alanının tanımı}

Araştırma alanı; güneyinde Kuşadası Körfezi, kuzeyinde Madra Dağları, batısında Çeşme Yarımadası, doğusunda ise Aydın, Manisa il sınırları ile çevrili olan Akdeniz iklim kuşağının ve Akdeniz Fitocoğrafya elementlerinin hakim olduğu İzmir ilidir (Şekil 1).

\section{Survey- envanter çalışmaları}

Arazi çalıșmalarına başlamadan önce hedef takson listesindeki bitkilerin yayılış gösterdikleri alanlar Türkiye Florası ile "IZ" ve "EGE" herbaryum kayıtlarından belirlenerek arazi çalışmaları için toplama takvimi oluşturulmuştur. Belirlenen lokalitelere 2014-2018 yılları arasında bitkilerin optimum geliştiği dönemlerde periyodik arazi çalışmaları düzenlenmiştir. $\mathrm{Bu}$ süre zarfinda araştırma alanının hemen hemen her yöresine gidilmiştir. Arazi çalışmaları, özellikle çiçeklenmenin yoğun olduğu ilkbahar-yaz-güz aylarında yapılmakla beraber kış aylarında da zaman zaman arazi çalışmalarına devam edilmiştir. Toplanan bitki örneklerinin tanımlama için gerek duyulan tüm kısımlarının olmasına (kök, gövde, yaprak, çiçek, meyve) ve soğanlı, yumrulu ve rizomlu bitkilerin toprak altı k1sımlarının da alınmasına dikkat edilmiștir.
Bitki örneklerinin toplama çalşmalarında arazi defteri kullanılmış ve her bir örnek için ayrı ayrı bilgiler not edilmiştir. Bu bilgiler:

a) Topalayıcı adı ve tarih: Toplama yapılan günün tarihi

b) Bitki numarası: Çalışmalar sırasında toplanan bitki örnekleri alım sırasına göre numaralandırılıp bitki örneklerinin sonradan bozulabilecek özellikleri not edildi.

c) Örnek alanın koordinatı: GPS koordinatları ile alanın yöresel ismi yazıldı.

d) Yükselti: Hata payı 5m olan GPS kullanılarak belirlendi.

e) Yöney: Pusulası da bulunan GPS yardımıyla bak1 tespit edildi.

f) Habitat ve yeryüzü şekli: Arazi gözlemleri ve topografîk harita yardımıyla alımın yapıldığ yer sırt, tepe, üst yamaç vb. olarak not edildi.

Ayrıca örnekler toplanırken bitkiler ve yaşam alanları fotoğraflanarak bitkilerin ayırt edici karakterleri ve fenotipik karakterleri not edilmiştir. Bitkilerin dökülebilen kısımları da göz önüne alınmış, renkleri değişebilecek çiçeklerin renklerinin not edilmesine dikkat edilmiştir.

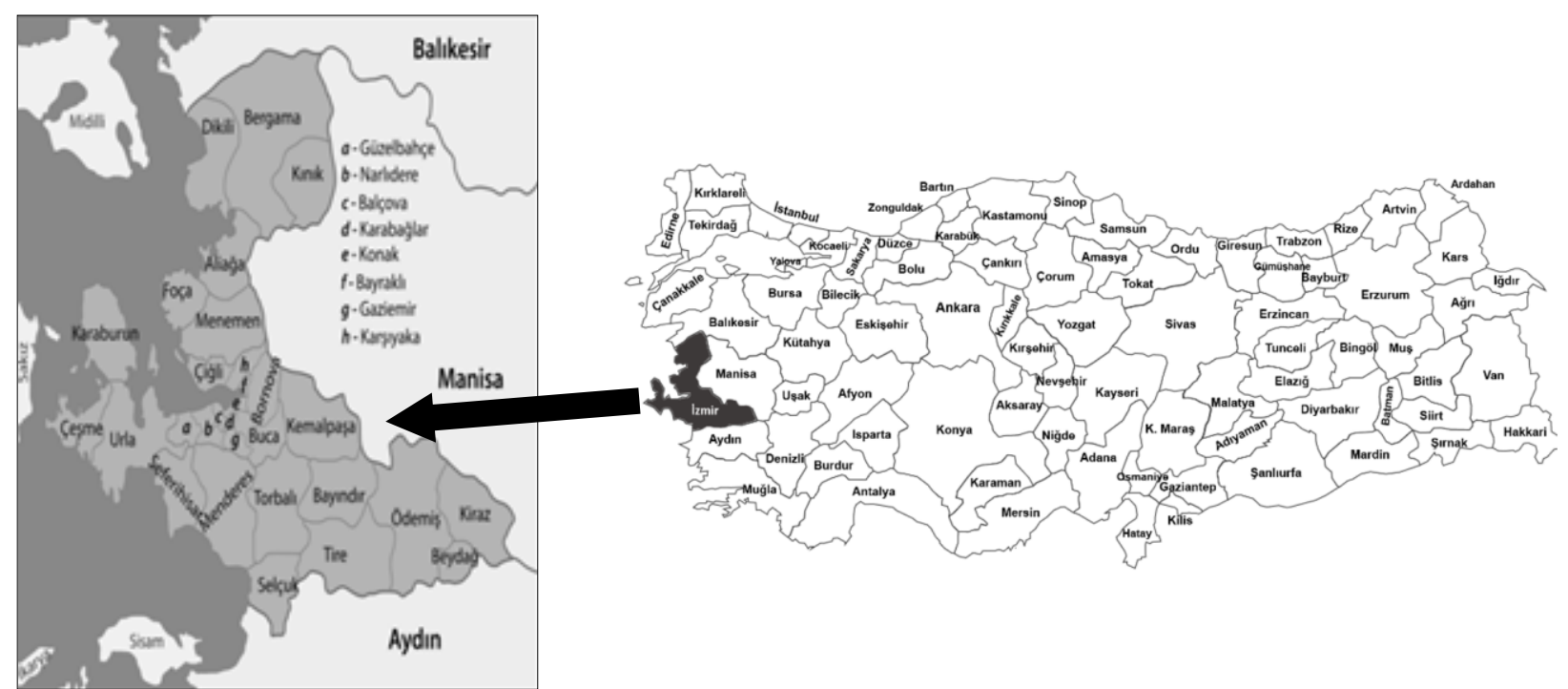

Şekil 1. Araştırma alanının haritası.

Figure 1. Map of the research area. 
Survey ve toplamalar sirasinda sadece herbaryum örneği değil ex situ muhafazaya alınmak üzere tohumlu bitki türlerinin tohumları da toplanmıştır (Hawkes, 1980).

\section{Herbaryum hazırlama ve botanik sınıflandırma}

Arazi çalışmaları esnasında bitki örnekleri mümkün olduğunca tüm tanımlayıcı parçalarıyla toplanmış ve her bitki kâğıt zarflara konularak Ege Tarımsal Araştırma Enstitüsü (ETAE) herbaryum hazırlık odasına getirilmiştir. Daha sonra bitkiler bilimsel yöntemlere uygun olarak kurutma kâğıtlarına koyularak pres içerisinde kurutulmuştur. Böylece uluslararası standartlara uygun herbaryum örnekleri 2014-2017 y1lları aras1 hazırlanmıştır (Tan ve Taşkın, 2001; Seçmen ve ark., 2008).

Herbaryum örneklerinin teşhişleri Ege Üniversitesi Fen Fakültesi Biyoloji Bölümü ile birlikte koordineli yapılmıştır. Herbaryum örnekleri familya ve cins düzeyinde teşhis edildikten sonra tür ve tür altı kategorilerinin teşhisi için temel kaynak olarak "Flora of Turkey" adlı 11 ciltlik eserlerde bulunan tür anahtarlarından yararlanılmıştır (Davis,19651985, Davis, ve ark., 1988; Güner ve ark., 2000). Ayrıca tür teşhislerinde "Flora Orientalis" (Boissier $1879,1884)$ 'in IV ve V. ciltlerinden, "Flora Aegaea" (Rechinger, 1943), "Flora of Europae" (Heywood ve Tutin, 1963-1980) ve "Mountanin Flora of Greece" (Strid ve Tan, 1986) adl eserlerden de faydalanılmıştır.

Takson isimlerinde yapılan aktarma, isim, endemizm ve tehlike kategorilerindeki statü değişiklikleri "The Plant List (a working list of all plant species)" (Anonymous, 2013a), "Türkiye Bitkileri Listesi (Damarlı Bitkiler)" (Güner ve ark., 2012) ve "Tehdit Altındaki Bitki Türleri Listesi" (Anonymous, 2018b)'ne göre güncellenmiştir.

\section{Muhafaza ve dokümantasyon çalışmaları}

Toplanan herbaryum örnekleri, böcek gibi zararlilardan korumak amaciyla derin dondurucularda 72 saat süreyle bekletilmiştir. Herbaryum örnekleri $30 \mathrm{~cm}$ x $42 \mathrm{~cm}$ boyutlarda beyaz renkli kartonlar üzerine su bazlı bantlar kullanılarak yapıştırılmıştır (Seçmen ve ark., 2008; Tan ve Taşkın, 2001). Bilimsel standartlara göre hazırlanmış örnekler uluslararası herbaryum indeksine kayıtlı (İZ) ETAE Herbaryumunda koruma altına alınmıştır.

Toplanan tohumlar laboratuvara getirilerek temizlenmiş ve etiketlenmiştir. Toplanan tohumların canlılık ve çimlendirme testleri yapılmıştır (Ellis ve ark., 1985). Tohum örnekleri uygun nem oranına ulaşıncaya kadar kontrollü şartlarda kurutulmuştur. Bitki genetik kaynakları tohum örneklerinin muhafaza ilkeleri doğrultusunda materyalin bir seti $0^{\circ} \mathrm{C}^{\prime}$ de orta süreli aktif koleksiyon olarak, ikinci seti ise eksi $20^{\circ} \mathrm{C}$ 'de uzun süreli baz koleksiyon olarak ETAE Ulusal Gen Bankasında muhafazaya alınmıştır (Tan, 2000). Ayrica, Salvia smyrnea ve Origanum sipyleum türleri doku kültüründe in vitro ortama aktarılarak kriyoprezervasyon yöntemleriyle muhafaza altına alma çalışmalarına başlanılmıştır.

Survey toplama sirasinda alınan herbaryum ve tohumlarla ilgili tüm bilgiler standart formatlara işlenmiştir. Herbaryum ve muhafazaya alınacak tohum örneklerinin toplama ve pasaport bilgileri yanında eğer varsa bölgenin özel adı, ekolojik özelliği gibi ek bilgiler de kayıt altına alınmıştır.

Çalışma kapsamında teşhisi yapılan örneklerin verileri TAGEM dijital herbaryumuna aktarılmıştır (Anonymous, 2013b).

\section{Farkındalık çalışmaları}

Bu çalışma kapsamında, özellikle T.C. Millî Eğitim Bakanlığından ve özel eğitim kurumlarından gelen öğrencilere yönelik sunumlar yapılarak ülkemizin biyoçeşitliliği ve endemizm konusunda farkındalık yaratılmaya ve koruma bilinci aşılamaya çalışılmıştır. Her yıl geleneksel olarak düzenlenen yöresel ve bölgesel festivallerde (Alaçatı Ot Festivali) "İzmir ili endemik bitkileri ve koruma çalışmaları" adı ile yerel halka sunumlar yapılmıştır. Endemik bitki türlerine ait afişler, broşürler, posterler ve katologlar hazırlanmıştır.

Bunlara ek olarak, bitkilerin tanınmasını sağlamak, görsel ve sanatsal olarak farkındalık yaratmak adına endemik bitkilerin doğal yaşam alanlarında çekilmiş fotoğraflarından oluşan "İzmir İli Endemik ve Nadir Bitkiler" adlı fotoğraf sergisi 29 Nisan 2019 tarihinde Türkiye'de Biyoçeşitlilik adlı etkinlikte geniş katılımlı (araştırma enstitüleri, il 
müdürlükleri, üniversiteler, okullar, bürokratlar, belediyeler) olarak gerçekleştirilmiştir.

\section{BULGULAR ve TARTIȘMA}

Survey ve toplama çalışmaları 2014-2018 yıllarında yapılmştır. Arazi çalışmaları, öncelikli olarak bitkilerin mevsimsel gelişimine paralel olarak herbaryum kayıtları ve literatür çalışmalarından tespit ettiğimiz hedef türlerce zengin alanları daha sık olmak koşuluyla İzmir ilinin hemen hemen her yerine gidilerek tamamlanmıştır.

İzmir ilinde 2014-2018 tarihleri arasında yapılan arazi çalışmalarıyla tespit edilen takson sayısı 430'dur. Toplanan verilerin değerlendirilmesi sonucunda 32 familyaya ait 91 cins ve 188 hedef taksona ulaşılmıştır (Çizelge 1 ve Şekil 2).
$\mathrm{Bu}$ türlerden 115 tanesi endemik, 48 tanesi tip örneği Türkiye olan, 13 tanesi nadir ve 12 tanesi endemik ya da nadir olmayı IUCN Kırmızı Liste Sinıflarına (IUCN, 2012) göre tehdit kategorisinde olan taksonlardır (Çizelge 1).

Yapılan arazi çalışmaları sonucunda tespit edilen taksonların IUCN tehdit kriterlerine göre tehlike kategorileri belirlenmiştir (Ekim ve ark., 2000; Anonymous, 2018b). Bu taksonlardan 1 takson EW (Doğada Tükenmiş), 6 takson CR (Kritik), 19 takson EN (Tehlikede), 36 takson VU (Duyarl1), 9 takson CD (Korumaya Tabi), 50 takson LC (Düşük Riskli), 14 takson NT (Tehdite Yakın) ve 3 takson "DD" (Veri Yetersiz) kategorisindedir (Çizelge1).

Çizelge 1. Çalışma kapsamında toplanan bitki listesi.

Table 1. List of collected materials in the study.

\begin{tabular}{|c|c|c|c|c|c|}
\hline Familya (Family) & Botanik ismi (Botanical name) & $\begin{array}{l}\text { Türkçe ismi } \\
\text { (Turkish name) }\end{array}$ & $\begin{array}{l}\text { Endemik durumu } \\
\text { (Endemic status) }\end{array}$ & \begin{tabular}{|c|} 
Tehlike \\
kategori* \\
(Threat \\
category) \\
\end{tabular} & \begin{tabular}{|l|} 
Tohum \\
toplamas1 \\
(Seed \\
collected) \\
\end{tabular} \\
\hline Amaryllidaceae & Allium pictistamineum $\mathrm{O}$. Schwarz & İzmir Soğanı & Endemik & $\mathrm{CD}$ & - \\
\hline Amaryllidaceae & Allium pseudoflavum Vved. & Küllü Soğan & - & $\mathrm{LC}$ & - \\
\hline Amaryllidaceae & Allium reuterianum Boiss. & Toros Cücesi & Tip örneği Türkiye ** & $\mathrm{LC}$ & - \\
\hline Amaryllidaceae & Allium sipyleum Boiss. & Sipilsoğanı & Tip örneği Türkiye & - & - \\
\hline Amaryllidaceae & Galanthus elwesii var. elwesii Hookf. & Kardelen & Tip örneği Türkiye & VU & - \\
\hline Amaryllidaceae & Galanthus gracilis Čelak. & İnce Kardelen & Nadir & VU & - \\
\hline Amaryllidaceae & Sternbergia schubertii var. mesogitana Schenk. & - & Nadir & - & - \\
\hline Apiaceae & Anthriscus tenerrima Boiss. \& Spruner & Zire & Tip örneği Türkiye & - & - \\
\hline Apiaceae & Bunium pinnatifolium Kljuykov & Tel Aksar & Endemik & VU & - \\
\hline Apiaceae & Ferula anatolica Boiss. & Özçakşır & Endemik & $\mathrm{CR}$ & + \\
\hline Apiaceae & Ferulago aucheri Boiss. & Yayla Kişnişi & Endemik & $\mathrm{LC}$ & - \\
\hline Apiaceae & Ferulago humulis Boiss. & Kilkuyruk & Endemik & $\mathrm{LC}$ & - \\
\hline Apiaceae & Heracleum platytaenium Boiss. & Öğrekotu & Tip örneği Türkiye & $\mathrm{LC}$ & + \\
\hline Apiaceae & Peucedanum guvenianum Yıldırım \& H.Duman & Efe Çakşırı & Endemik & - & - \\
\hline Apiaceae & Prangos hulusii Şenol, Yıldırım \& Seçmen & Hulusi Çakşırı & Endemik & - & - \\
\hline Apocynaceae & Vincetoxium tmoleum Boiss. & Hiyaluk & - & - & + \\
\hline Asparagaceae & Ornithogalum nivale Boiss. & Narinyıldız & Endemik & $\mathrm{LC}$ & - \\
\hline Asparagaceae & Ruscus aculeatus var. angustifolius $\mathrm{L}$. & Tavşanmemesi & - & VU & - \\
\hline Asparagaceae & Scilla luciliae (Boiss.) Speta & Bozdağ Sümbülü & Endemik & - & + \\
\hline Asparagaceae & Scilla sardensis (Whittall ex Barr \& Sayden) Speta & Gökçekarlık & Endemik & VU & + \\
\hline Asparagaceae & Scilla siehei (Boiss.) Speta & Nif Karyıldızı & Endemik & - & + \\
\hline Asparagaceae & Scilla $x$ allenii (G.Nicholson) Speta & Melez Karyıldızı & Endemik & EN & - \\
\hline Asteraceae & Achillea nobilis subsp. sipylea (O.Schwarz) Bässler & Kabe Fesleğeni & Endemik & NT & - \\
\hline Asteraceae & Cota dipsacea (Bornm.) Oberp. \& Greuter & Başbabuçça & Endemik & EN & + \\
\hline Asteraceae & Anthemis aciphylla var. discoidea Boiss. & İğne Papatyas1 & Endemik & $\mathrm{LC}$ & + \\
\hline Asteraceae & Anthemis cretica subsp. anatolica (Boiss.) Grierson & Horozpapatyası & Tip örneği Türkiye & - & + \\
\hline Asteraceae & Anthemis xylopoda O. Schwarz & İzmir Papatyas1 & Endemik & $\mathrm{CR}$ & + \\
\hline
\end{tabular}


Çizelge 1. (devam).

Table 1. (continued).

\begin{tabular}{|c|c|c|c|c|c|}
\hline Familya (Family) & Botanik ismi (Botanical name) & $\begin{array}{l}\text { Türkçe ismi } \\
\text { (Turkish name) }\end{array}$ & $\begin{array}{l}\text { Endemik durumu } \\
\text { (Endemic status) }\end{array}$ & \begin{tabular}{|c|} 
Tehlike \\
kategori* \\
(Threat \\
category)
\end{tabular} & \begin{tabular}{|l|} 
Tohum \\
toplamas1 \\
(Seed \\
collected) \\
\end{tabular} \\
\hline Asteraceae & Cota wiedemanniana (Fisch. \& C.A.Mey.) Holub & Bodurbabuçça & Tip örneği Türkiye & $\mathrm{LC}$ & - \\
\hline Asteraceae & Carduus tmoleus subsp. tmoleus Boiss. & Bozdağ Kangalı & Tip örneği Türkiye & - & + \\
\hline Asteraceae & Cyanus thirkei (Sch.Bip.) Holub & & Tip örneği Türkiye & - & - \\
\hline Asteraceae & Centaurea amasiensis Bornm. & $\begin{array}{l}\text { Amasya } \\
\text { Peygamberçiçeği }\end{array}$ & Endemik & $\mathrm{LC}$ & - \\
\hline Asteraceae & Centaurea aphrodisea Boiss. & İraz Düğme & Endemik & VU & + \\
\hline Asteraceae & Centaurea calolepis Boiss. & Şaladır & Endemik & $\mathrm{LC}$ & - \\
\hline Asteraceae & Centaurea cariensis Boiss. & Acımıkotu & Tip örneği Türkiye & VU & - \\
\hline Asteraceae & Centaurea lydia Boiss. & Gür Kötürüm & Endemik & $\mathrm{CD}$ & - \\
\hline Asteraceae & Centaurea polyclada D.C. & Yedi Düğme & Endemik & VU & - \\
\hline Asteraceae & Centaurea urvillei subsp. stepposa Wagenitz & Yerkötürümü & Tip örneği Türkiye & $\mathrm{LC}$ & - \\
\hline Asteraceae & Centaurea zeybekii Wagenitz & Efe Düğmesi & Endemik & EN & + \\
\hline Asteraceae & $\begin{array}{l}\text { Rhaponticoides mykalea (Hub.-Mor.) M.V.Agab. } \\
\text { \& Greuter }\end{array}$ & Aydıngaşağ & Endemik & $\mathrm{CR}$ & + \\
\hline Asteraceae & Cirsium sipyleum O. Schwarz & Çelebi Kangalı & Endemik & NT & + \\
\hline Asteraceae & Hieracium tmoleum Hub.-Mor. & Acı Şahinotu & Endemik & EN & + \\
\hline Asteraceae & Inula oculus-christi subsp. auriculata $\mathrm{L}$. & Yolotu & Endemik & NT & \\
\hline Asteraceae & Inula anatolica Boiss. & Kayaandızı & Tip örneği Türkiye & $\mathrm{LC}$ & + \\
\hline Asteraceae & Inula germanica $\mathrm{L}$. & Ekinandızotu & Nadir & - & + \\
\hline Asteraceae & Jurinea cadmea subsp. cadmea Boiss. & Bodur Göbek & Endemik & VU & + \\
\hline Asteraceae & Jurinea cadmea subsp. nifensis Yıldırım \& Şenol & Nif Bodur Göbeği & Endemik & VU & - \\
\hline Asteraceae & Pilosella $x$ macrotricha F.W.Schultz \& Sch.Bip. & Keçetırnakotu & Tip örneği Türkiye & - & - \\
\hline Asteraceae & Senecio bicolor subsp. bicolor (Willd) Tod. & Külçiçeği & - & VU & - \\
\hline Asteraceae & Senecio castagneanus D.C. & Çalı Kanaryaotu & Endemik & $\mathrm{LC}$ & - \\
\hline Asteraceae & Tragopogon subacaulis O. schwarz & Çobanyemi & Endemik & EN & - \\
\hline Asteraceae & Tripleurospermum hygrophilum Bornm. & Su Papatyası & Endemik & EN & - \\
\hline Boraginaceae & Symphytum anatolicum Boiss. & Ana Kafesotu & Tip örneği Türkiye & $\mathrm{LC}$ & - \\
\hline Boraginaceae & Moltkia aurea Boiss. & Sarıkesen & Endemik & $\mathrm{LC}$ & + \\
\hline Brassicaceae & Alyssum borzaeanum Nyár. & - & Endemik & - & - \\
\hline Brassicaceae & Alyssum erosulum Gennari \& Pestal. ex Clem. & Çentiklikevke & Endemik & $\mathrm{LC}$ & - \\
\hline Brassicaceae & Alyssum fulvescens var. stellatocarpum Hub.-Mor. & Egekuduzotu & Endemik & - & - \\
\hline Brassicaceae & $\begin{array}{l}\text { Draba bruniifolia subsp. archipelagi (O.E.Schulz) } \\
\text { Coode \& Cullen }\end{array}$ & Tüylüdolama & Tip örneği Türkiye & - & - \\
\hline Brassicaceae & $\begin{array}{l}\text { Draba bruniifolia subsp. olympica (Sibth. ex DC.) } \\
\text { Coode \& Cullen }\end{array}$ & Ulu Dolama & Tip örneği Türkiye & - & + \\
\hline Brassicaceae & Erysimum carium Boiss. & Antalya Zarifesi & Endemik & $\mathrm{CR}$ & - \\
\hline Brassicaceae & Erysimum pusillum Bory \& Chaub. & Cüce Zarifeotu & - & VU & - \\
\hline Brassicaceae & Hesperis balansae E.Fourn. & Akşam Itırı & Tip örneği Türkiye & EN & - \\
\hline Brassicaceae & Matthiola montana Boiss. & Akdağşebboyu & Endemik & NT & \\
\hline Campanulaceae & $\begin{array}{l}\text { Asyneuma limonifolium subsp. pestalozzae (Boiss.) } \\
\text { Damboldt }\end{array}$ & Tavşan Katığı & Endemik & $\mathrm{LC}$ & + \\
\hline Campanulaceae & Campanula betonicifolia Sibth. \& Sm. & Uluçıngırak & Endemik & $\mathrm{LC}$ & + \\
\hline Campanulaceae & Campanula leblebici Y1ldırım. & İzmirçanı & Endemik & - & - \\
\hline Campanulaceae & Campanula lyrata subsp. lyrata Lam. & Memek & Endemik & $\mathrm{LC}$ & - \\
\hline Campanulaceae & Campanula mugeana Yıldırım. & Müge Çançiçeği & Endemik & - & - \\
\hline Campanulaceae & Campanula raveyi Boiss. & Efe Çıngırağ 1 & Endemik & EN & + \\
\hline Campanulaceae & Campanula teucrioides Boiss. & Bozdağ Çanı & Endemik & VU & + \\
\hline
\end{tabular}


E. OĞUR: İZMIR İLINDE BULUNAN NADIR, ENDEMIK VE TEHDİT ALTINDAKI BITKI TÜRLERININ TOPLANMASI VE EX SITU MUHAFAZASI

Çizelge 1. (devam).

Table 1. (continued).

\begin{tabular}{|c|c|c|c|c|c|}
\hline Familya (Family) & Botanik ismi (Botanical name) & $\begin{array}{l}\text { Türkçe ismi } \\
\text { (Turkish name) }\end{array}$ & $\begin{array}{l}\text { Endemik durumu } \\
\text { (Endemic status) }\end{array}$ & \begin{tabular}{|c|} 
Tehlike \\
kategori* \\
(Threat \\
category)
\end{tabular} & \begin{tabular}{|l|} 
Tohum \\
toplamas1 \\
(Seed \\
collected)
\end{tabular} \\
\hline Campanulaceae & Campanula tomentosa Lam. & Yakalı Çan & Endemik & VU & + \\
\hline Campanulaceae & Campanula vardariana Bocquet. & Vardar Çanı & Endemik & - & \\
\hline Campanulaceae & Jasione supina subsp. tmolea (Stoj.) Damboldt & Bozdağ Gökçesi & Endemik & VU & + \\
\hline Caprifoliaceae & Scabiosa hispidula Boiss. & Killiuyuzotu & Tip örneği Türkiye & VU & - \\
\hline Caryophyllaceae & Arenaria tmolea Boiss. & Honaz Kumotu & Endemik & $\mathrm{LC}$ & + \\
\hline Caryophyllaceae & Dianthus anatolicus Boiss. & Yabani Karanfil & Tip örneği Türkiye & $\mathrm{LC}$ & + \\
\hline Caryophyllaceae & Dianthus elegans d'Urv. & Delikaranfil & - & $\mathrm{LC}$ & \\
\hline Caryophyllaceae & Dianthus erinaceus var. erinaceus Boiss. & Kümekaranfil & Endemik & VU & + \\
\hline Caryophyllaceae & Dianthus zonatus Fenzl. & Kayakaranfili & Tip örneği Türkiye & & - \\
\hline Caryophyllaceae & Gypsophila tubulosa (Jaub. \& Spach) Boiss. & Ege Çevgeni & Endemik & VU & - \\
\hline Caryophyllaceae & $\begin{array}{l}\text { Minuartia anatolica subsp. anatolica (Boiss.) } \\
\text { Woronow }\end{array}$ & Tistisotu & Endemik & $\mathrm{LC}$ & - \\
\hline Caryophyllaceae & Minuartia juressi subsp. asiatica McNeill & İzmir Tistıs1 & Tip örneği Türkiye & $\mathrm{LC}$ & + \\
\hline Caryophyllaceae & Minuartia multinervis (Boiss.) Bornm. & Meşetıstıs1 & Tip örneği Türkiye & & - \\
\hline Caryophyllaceae & Minuartia nifensis McNeill & Nif Tistis1 & Endemik & EN & + \\
\hline Caryophyllaceae & Minuartia recurva subsp. carica McNeill & Baba Tistis & Endemik & VU & + \\
\hline Caryophyllaceae & Minuartia saxifraga subsp. tmolea Mattf. & Bozdağ Tistısı & Endemik & VU & + \\
\hline Caryophyllaceae & Paronychia anatolica subsp. balansae Chaudhri & Ege Etyaranı & Endemik & VU & - \\
\hline Caryophyllaceae & Saponaria chlorifolia Kunze. & Tahdikotu & Endemik & $\mathrm{LC}$ & - \\
\hline Caryophyllaceae & $\begin{array}{l}\text { Silene caramanica } \text { var. idaea (Hausskn.) K.Yıldız } \\
\text { \& Çırpıcı }\end{array}$ & - & Endemik & $\mathrm{LC}$ & - \\
\hline Caryophyllaceae & Silene gallica $\mathrm{L}$. & Serçeçiçeği & Tip örneği Türkiye & - & - \\
\hline Caryophyllaceae & Silene rhynchocarpa Boiss. & Gagalı Nak11 & Tip örneği Türkiye & - & + \\
\hline Caryophyllaceae & Velezia hispida Boiss. \& Balansa & Killı T1ğotu & Endemik & LC & - \\
\hline Caryophyllaceae & Velezia pseudorigida Hub.-Mor. & Has Tiğotu & Endemik & VU & - \\
\hline Cistaceae & Cistus monspeliensis L. & Pamukluk & Nadir & VU & - \\
\hline Colchicaceae & Colchicum micaceum K.Perss. & Baba Mahrutu & Endemik & EN & - \\
\hline Crassulaceae & $\begin{array}{l}\text { Sedum eriocarpum subsp. caricum (Carlström) 't } \\
\text { Hart }\end{array}$ & Ada Damkoruğu & Endemik & EN & - \\
\hline Crassulaceae & Sedum lydium Boiss. & Ege Koruğu & Endemik & $\mathrm{LC}$ & - \\
\hline Euphorbiaceae & Euphorbia anacampseros var. tmolea Boiss. & Sütlüağu & Endemik & VU & + \\
\hline Euphorbiaceae & Euphorbia erythrodon Boiss. \& Heldr. & Kızıl Sütleğen & Endemik & $\mathrm{LC}$ & - \\
\hline Fabaceae & $\begin{array}{l}\text { Astragalus angustiflorus subsp. anatolicus (Boiss.) } \\
\text { D.F.Chamb. }\end{array}$ & Ana Geven & Endemik & - & - \\
\hline Fabaceae & Astragalus flavescens Boiss. & Sar1 Geven & Endemik & - & + \\
\hline Fabaceae & Astragalus ptilodes var. cariensis Boiss. & - & Tip örneği Türkiye & - & - \\
\hline Fabaceae & Astragalus ptilodes var. ptilodes Boiss. & Spil Geveni & Tip örneği Türkiye & - & - \\
\hline Fabaceae & Astragalus tmoleus var. tmoleus Boiss. & Bozdağ Geveni & Endemik & - & + \\
\hline Fabaceae & Astragalus trojanus Steven. & Çanakkale Geveni & Tip örneği Türkiye & - & - \\
\hline Fabaceae & Cytisus orientalis Loisel. & Şarktırfilı & Endemik & VU & + \\
\hline Fabaceae & $\begin{array}{l}\text { Colutea melanocalyx subsp. davisiana (Browicz) } \\
\text { D.F.Chamb. }\end{array}$ & \begin{tabular}{|l|}
$\begin{array}{l}\text { Kara Patlangaç } \\
\text { (Keçigevişi) }\end{array}$ \\
\end{tabular} & Tip örneği Türkiye & $\mathrm{LC}$ & - \\
\hline Fabaceae & Genista anatolica Boiss. & Kandaşdikeni & Tip örneği Türkiye & - & - \\
\hline Fabaceae & $\begin{array}{l}\text { Genista januensis subsp. lydia (Boiss.) Kit Tan \& } \\
\text { Zie }\end{array}$ & Geyik Borçağı & Tip örneği Türkiye & - & - \\
\hline Fagaceae & Quercus aucheri Jaub. \& Spach & Bozpırnal & Endemik & $\mathrm{CD}$ & - \\
\hline Gentianaceae & Gentiana lutea subsp. lutea L. & Sarıafat & - & EN & - \\
\hline
\end{tabular}


Çizelge 1. (devam).

Table 1. (continued).

\begin{tabular}{|c|c|c|c|c|c|}
\hline Familya (Family) & Botanik ismi (Botanical name) & $\begin{array}{l}\text { Türkçe ismi } \\
\text { (Turkish name) }\end{array}$ & $\begin{array}{l}\text { Endemik durumu } \\
\text { (Endemic status) }\end{array}$ & \begin{tabular}{|c|} 
Tehlike \\
kategori* \\
(Threat \\
category)
\end{tabular} & \begin{tabular}{|l} 
Tohum \\
toplamas1 \\
(Seed \\
collected)
\end{tabular} \\
\hline Hypericaceae & Hypericum adenotrichum Spach & Kizılcıkotu & Endemik & $\mathrm{LC}$ & - \\
\hline Hypericaceae & Hypericum aviculariifolium Jaub\&Spach & Mide Otu & Endemik & LC & - \\
\hline Iridaceae & Crocus biflorus subsp. nubigena (Herb.) B.Mathew & Bulut Çiğdemi & Tip örneği Türkiye & $\mathrm{LC}$ & - \\
\hline Iridaceae & Crocus chrysanthus subsp. sipyleus & - & Endemik & - & - \\
\hline Iridaceae & Crocus fleischeri J.Gay. & Taşlık Çiğdemi & Tip örneği Türkiye & $\mathrm{LC}$ & - \\
\hline Iridaceae & Crocus gargaricus subsp. gargaricus Herb. & Kazçiğdemi & Endemik & NT & - \\
\hline Iridaceae & $\begin{array}{l}\text { Crocus olivieri subsp. balansae (J.Gay ex Maw) } \\
\text { B.Mathew }\end{array}$ & Koru Çiğdemi & Tip örneği Türkiye & NT & - \\
\hline Iridaceae & Gladiolus anatolicus (Boiss.) Stapf & Ekin Çiçeği & Tip örneği Türkiye & $\mathrm{LC}$ & - \\
\hline Isoetaceae & Isoetes histrix var. histrix Bory. & Çimeğreltisi & - & DD & - \\
\hline Lamiaceae & Ajuga bombycina Boiss. & Geyik Mayasılı & Endemik & NT & - \\
\hline Lamiaceae & $\begin{array}{l}\text { Lavandula pedunculata subsp. cariensis (Boiss.) } \\
\text { Upson \& S.Andrews }\end{array}$ & Karan & Tip örneği Türkiye & NT & + \\
\hline Lamiaceae & Marrubium rotundifolium Boiss. & Kalartopu & Endemik & $\mathrm{LC}$ & - \\
\hline Lamiaceae & Marrubium bourgaei Boiss. & Bozkaşık & Endemik & NT & + \\
\hline Lamiaceae & $\begin{array}{l}\text { Micromeria cristata } \text { subsp. cristata (Hampe) } \\
\text { Griseb. }\end{array}$ & Kayaboğumcuğu & - & - & - \\
\hline Lamiaceae & Nepeta cadmea Boiss. & Honaz Pisikotu & Endemik & $\mathrm{LC}$ & + \\
\hline Lamiaceae & Nepeta nuda subsp. lydiae P.H.Davis & Babaküncü & Endemik & NT & \\
\hline Lamiaceae & Nepeta viscida Boiss. & Yağl1 Pisikotu & Endemik & NT & + \\
\hline Lamiaceae & Nepeta lamiifolia Willd. & Dağpisikotu & - & - & + \\
\hline Lamiaceae & Origanum sipyleum $\mathrm{L}$. & Mormercan & Endemik & LC & + \\
\hline Lamiaceae & Phlomis bourgaei Boiss. & Çoban Çırası & Tip örneği Türkiye & NT & - \\
\hline Lamiaceae & Phlomis carica Rech. f. & Makiçalbası & Endemik & $\mathrm{CD}$ & - \\
\hline Lamiaceae & Phlomis nissolii L. & Öbek Çalba & Endemik & $\mathrm{LC}$ & - \\
\hline Lamiaceae & Salvia smyrnaea Boiss. & Nif Şalbası & Endemik & EN & + \\
\hline Lamiaceae & $\begin{array}{l}\text { Scutellaria brevibracteata subsp. brevibracteata } \\
\text { Stapf. }\end{array}$ & Yağlı Kaside & Endemik & - & - \\
\hline Lamiaceae & Sideritis sipylea Boiss. & Spil Çayı & Endemik & NT & + \\
\hline Lamiaceae & Sideritis tmolea P.H.Davis & Bozdağ Sivriçayı & Endemik & $\mathrm{CD}$ & + \\
\hline Lamiaceae & Stachys cretica subsp. smyrnaea Rechf. & İzmirdeliçayı & Endemik & $\mathrm{LC}$ & + \\
\hline Lamiaceae & Stachys tmolea Boiss. & Sürmeli Çayçe & Endemik & $\mathrm{LC}$ & + \\
\hline Lamiaceae & Thymus cilicicus Boiss. \& Balansa & Kılçıkkekiği & Tip örneği Türkiye & $\mathrm{LC}$ & + \\
\hline Lamiaceae & Thymus sipyleus Boiss. & Spil Kekiği & Tip örneği Türkiye & $\mathrm{LC}$ & + \\
\hline Lamiaceae & Thymus zygioides var. lycaonicus Griseb. & Bodurkekiği & Tip örneği Türkiye & $\mathrm{LC}$ & - \\
\hline Lamiaceae & Thymuss zygioides subsp. zygioides & Bodurkekiği & Tip örneği Türkiye & & - \\
\hline Lamiaceae & $\begin{array}{l}\text { Ziziphora taurica subsp. clenioides (Boiss.) } \\
\text { P.H.Davis }\end{array}$ & Nane Ruhu & Endemik & $\mathrm{CD}$ & + \\
\hline Lamiaceae & $\begin{array}{l}\text { Lamium orientale (Fisch. \& C.A.Mey.) } \\
\text { E.H.L.Krause }\end{array}$ & Güzelce & Tip örneği Türkiye & - & - \\
\hline Liliaceae & $\begin{array}{l}\text { Fritillaria fleischeriana Steud. \& Hochst. ex } \\
\text { Schult. \& Schult. f. }\end{array}$ & Bozkır Lalesi & Endemik & - & + \\
\hline Liliaceae & Fritillaria bithynica Baker. & Deli Lale & Tip örneği Türkiye & - & - \\
\hline Liliaceae & Fritillaria carica subsp. carica Rix. & Bodursar1 & Tip örneği Türkiye & & + \\
\hline Liliaceae & Fritillaria milasense Tekşen \& Aytaç & Milas Lalesi & Endemik & - & - \\
\hline Liliaceae & Fritillaria pinardii Boiss. & Mahçup Lale & Tip örneği Türkiye & - & - \\
\hline Liliaceae & Tulipa clusiana D.C. & Çelebi Lalesi & - & EW & - \\
\hline
\end{tabular}


E. OĞUR: İZMIR İLINNDE BULUNAN NADIR, ENDEMIKK VE TEHDİT

Çizelge 1. (devam).

Table 1. (continued).

\begin{tabular}{|c|c|c|c|c|c|}
\hline Familya (Family) & Botanik ismi (Botanical name) & $\begin{array}{l}\text { Türkçe ismi } \\
\text { (Turkish name) }\end{array}$ & $\begin{array}{l}\text { Endemik durumu } \\
\text { (Endemic status) }\end{array}$ & $\begin{array}{c}\text { Tehlike } \\
\text { kategori* } \\
\text { (Threat } \\
\text { category) }\end{array}$ & $\begin{array}{l}\text { Tohum } \\
\text { toplamas1 } \\
\text { (Seed } \\
\text { collected) }\end{array}$ \\
\hline Linaceae & Linum aretioides Boiss. & Has Keten & Endemik & VU & - \\
\hline Linaceae & Linum tmoleum Boiss. & Mavi Keten & Endemik & NT & - \\
\hline Marsileaceae & Pilularia minuta Durieu ex A.Br. & Tel Tirfil & - & DD & - \\
\hline Orchidaceae & Ophrys sancti-isidorii Saliaris\&A.Alibertis & & Nadir & EN & - \\
\hline Orchidaceae & Ophrys attaviria subsp. cesmeensis Kreutz & Çesmesalebi & Nadir & $\mathrm{CR}$ & - \\
\hline Orchidaceae & $\begin{array}{l}\text { Himantoglossum comperianum (Steven) } \\
\text { P.Delforge }\end{array}$ & Meşekeşkeşi & Nadir & - & - \\
\hline Orchidaceae & Ophrys ferrum-equinum Desf. & Nallisalep & Nadir & - & - \\
\hline Orchidaceae & Orchis lactea Poir. & Albenli & Nadir & VU & \\
\hline Orchidaceae & Dactylorhiza pythagorae Gölz \& H. R. Reinhard & & Nadir & EN & - \\
\hline Orchidaceae & Ophrys apollonae & Uçarısalep & Nadir & $\mathrm{CR}$ & - \\
\hline Orchidaceae & Ophrys gortynia & & Nadir & $\mathrm{CR}$ & - \\
\hline Papaveraceae & Corydalis lydica Lidén & Kirli Kazgagası & Endemik & EN & + \\
\hline Papaveraceae & Corydalis wendelboi subsp. wendelboi Lidén & Tarlakuşu & Endemik & EN & - \\
\hline Papaveraceae & Papaver argemone subsp. argemone $\mathrm{L}$. & Kara Göbek & Endemik & VU & - \\
\hline Papaveraceae & Papaver argemone subsp. davisii Kadereit & Karagöbek & Endemik & VU & - \\
\hline Papaveraceae & Papaver pilosum subsp. pilosum Sibth. \& Sm. & Kellâle & Endemik & VU & + \\
\hline Plantaginaceae & Veronica cuneifolia D. Don. & Yer Mavişi & Endemik & $\mathrm{LC}$ & - \\
\hline Plumbaginaceae & Armeria cariensis var. cariensis Boiss. & Çim Menekşesi & Tip örneği Türkiye & - & - \\
\hline Polygonaceae & Rumex tmoleus Boiss. & Özge Labada & Endemik & VU & + \\
\hline Primulaceae & Cyclamen hederifolium Aiton. & Kandilkökü & - & VU & - \\
\hline Ranunculaceae & Anemone coronaria $\mathrm{L}$. & Manisalâlesi & - & VU & - \\
\hline Ranunculaceae & $\begin{array}{l}\text { Ranunculus isthmicus subsp. tenuifolius (Steven) } \\
\text { P.H.Davis }\end{array}$ & İnce Köstebekotu & Endemik & VU & - \\
\hline Rosaceae & Pyrus anatolica Browicz & Som Ahlat & Endemik & EN & - \\
\hline Rubiaceae & Asperula daphneola O. Schwarz & Yatık Belumotu & Endemik & VU & - \\
\hline Rubiaceae & Asperula lilaciflora subsp. lilaciflora Boiss. & Mor Belumotu & Endemik & $\mathrm{LC}$ & - \\
\hline Rubiaceae & $\begin{array}{l}\text { Asperula lilaciflora subsp. phrygia (Bornm.) } \\
\text { Schönb.-Tem. }\end{array}$ & Sarmaş Belum & Endemik & $\mathrm{LC}$ & - \\
\hline Rubiaceae & Asperula tenuifolia Boiss. & Spil Belumu & Tip örneği Türkiye & $\mathrm{LC}$ & - \\
\hline Rubiaceae & Galium brevifolium subsp. brevifolium $\mathrm{Sm}$. & Sünnetlikotu & Endemik & - & - \\
\hline Rubiaceae & Galium campaneliferum Ehrend. \& Schönb.-Tem. & Çan İplikçiği & Endemik & $\mathrm{CD}$ & - \\
\hline Rubiaceae & Galium incanum subsp. centrale Ehrend. & Külah İplikçiği & Endemik & $\mathrm{LC}$ & - \\
\hline Rubiaceae & Galium penduliflorum Boiss. & Sarkık İplikçik & Endemik & $\mathrm{LC}$ & - \\
\hline Scrophulariaceae & Scrophularia cryptophila Boiss.\& Heldr. & Ören Siracaotu & Endemik & - & - \\
\hline Scrophulariaceae & Scrophularia depauperata Boiss. & Koru Siracaotu & Endemik & - & + \\
\hline Scrophulariaceae & Verbascum cheiranthifolium Boiss. & Bozkulak & - & - & - \\
\hline Scrophulariaceae & Verbascum lobatum Hub.-Mor. & \begin{tabular}{|l|l|} 
Tokalı \\
S1ğırkuyruğu \\
\end{tabular} & Endemik & VU & - \\
\hline Scrophulariaceae & Verbascum lydium var. lydium Boiss. & Akgömlek & Endemik & NT & + \\
\hline Scrophulariaceae & Verbascum maeandri Bornm. & \begin{tabular}{|l|} 
Selçuk \\
Sığırkuyruğu
\end{tabular} & Endemik & EN & - \\
\hline Scrophulariaceae & Verbascum napifolium Boiss. & \begin{tabular}{|l|} 
Kıraç \\
Sığııkuyruğu
\end{tabular} & Endemik & $\mathrm{CD}$ & - \\
\hline Scrophulariaceae & Verbascum parviflorum Lam. & Balıkağısı & Endemik & $\mathrm{LC}$ & \\
\hline Scrophulariaceae & Verbascum phrygium Bornm. & \begin{tabular}{|l|} 
Sultan \\
Sığırkuyruğu
\end{tabular} & Endemik & $\mathrm{CD}$ & + \\
\hline
\end{tabular}


Çizelge 1. (devam).

Table 1. (continued).

\begin{tabular}{|l|l|l|l|c|c|}
\hline Familya (Family) & Botanik ismi (Botanical name) & $\begin{array}{l}\text { Türkçe ismi } \\
\text { (Turkish name) }\end{array}$ & $\begin{array}{l}\text { Endemik durumu } \\
\text { (Endemic status) }\end{array}$ & $\begin{array}{l}\text { Tehlike } \\
\text { kategori* } \\
\text { (Threat } \\
\text { category) }\end{array}$ & $\begin{array}{l}\text { Tohum } \\
\text { toplamasi } \\
\text { (Seed } \\
\text { collected) }\end{array}$ \\
\hline Scrophulariaceae & Verbascum pinnatifidum Vahl. & Dedengil & Tip örneği Türkiye & - & \\
\hline Scrophulariaceae & Verbascum rupicola (Hayek \& Siehe) Hub.-Mor. & $\begin{array}{l}\text { Kaya } \\
\text { Sığırkuyruğu }\end{array}$ & Endemik & DD & + \\
\hline Scrophulariaceae & Verbascum smyrnaeum Boiss. & $\begin{array}{l}\text { İzmir } \\
\text { Sığırkuyruğu }\end{array}$ & Endemik & DD & + \\
\hline Scrophulariaceae & Verbascum splendidum Boiss. & $\begin{array}{l}\text { Rana } \\
\text { Sığırkuyruğu }\end{array}$ & Tip örneği Türkiye & LC & - \\
\hline
\end{tabular}

" Tehlike Kategorisi (Threat Category) : DD: Yetersiz Veri - Data Deficient / NT: Tehdite Yakın - Near Threatened / LC: Düşük Riskli - Least Concern / CD: Korumaya Tabi - Conservation Dependent / VU: Duyarl - Vulnerable / EN: Tehlikede Endangered / CR: Kritik - Critically Endangered / WE: Doğada Tükenmiş - Extinct in the Wild.

${ }^{* * *}$ Tip Örneği Türkiye: İlk olarak Türkiye'de bulunup bilim dünyasına tanıtılan endemik olan bitkilerin daha sonra komşu ülkelerde bulunup endemikten düşmesini ifade eder. (Type Example Turkey: It refers to the endemic plants that were first found in Turkey and introduced to the scientific community, and then found in neighboring countries and fell out of endemic category).

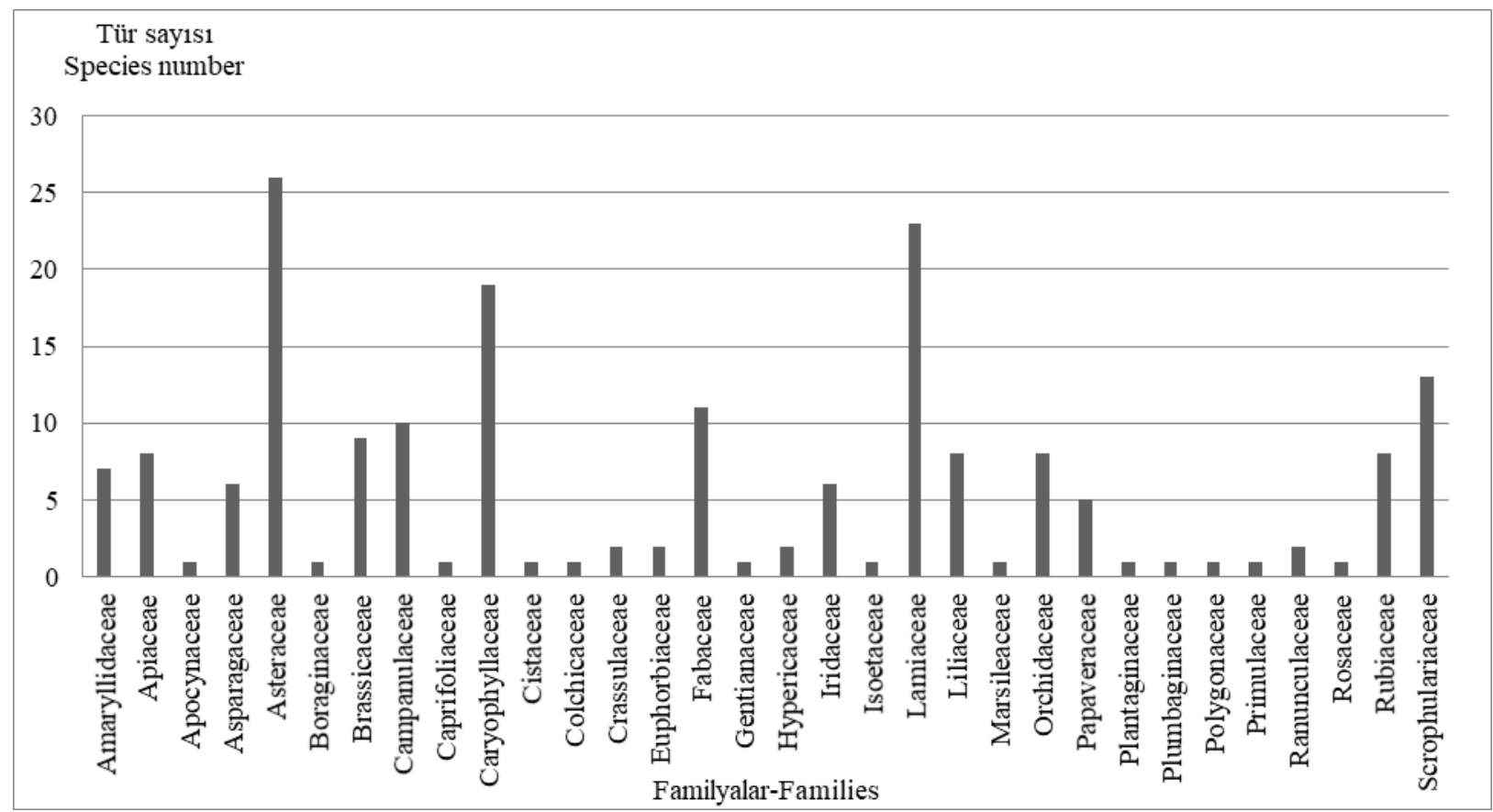

Şekil 2. Hedef Taksonların familya bazında dağılımı.

Figure 2. Distrubution of target taxons by families.

Çiçekli örnekleri alınan hedef türlerin belirlenen lokalitelerine tohum örnekleri alınmak üzere arazi çalışmaları yapılmıştır. Yapılan çalışmalar sonununda 15 familya 41 cinse ait 75 taksonun tohum örneği toplanmışır. Bu türlerden 60 tanesi endemik, 7 tanesi tip örneği Türkiye olan, 8 tanesi nadir taksonlardır. Tohumların IUCN tehdit kriterlerine göre tehlike kategorilerine bakılacak olursa bu taksonlardan, 6 takson CR (Kritik), 8 takson EN (Tehlikede), 14 takson VU (Duyarlı), 3 takson CD (Korumaya Tabi), 18 takson LC (Düşük Riskli), 7 takson NT (Tehdite Yakın) ve 1 takson "DD" (Veri Yetersiz) kategorisindedir (Çizelge 1).

Tohum materyalleri ETAE Ulusal Gen Bankasında muhafazaya alınması için toplama formlarıyla birlikte ETAE Biyoçeşitlilik ve Genetik Kaynaklar Bölümü Dökümantasyon birimine teslim edilmiştir. 
Arazi çalışmaları sırasında tehdit altında olan türlerin toplanması ile yetinilmemiş, çalışmanın amacına uygun olarak doğal yaşam alanlarını baskı altına alan biyotik faktörler belirlenmiş ve bunlarla ilgili koruma önerileri ortaya koyulmuştur.

Bir bitkinin tehdit altında olup olmadığ 1 belirlemek için o alanda çalışan bilim adamlarının Anonymous, (2012)'ye göre floristik çalışmalardan elde ettikleri verilere ve halkın deneyim ve gözlemlerine ihtiyaç duyulmaktadır. Yayılış alanları ve birey sayıları geçmiş yıllardaki verilere göre azalan bitkiler gelecekteki varlıkları açısından tehdit altında demektir (Anonymous, 2018b).

Endemik ve nadir türlerin koruma statülerinin kesin olarak bilinmesi onların soylarının tükenmesinin önüne geçecek olan koruma stratejilerinin belirlenmesindeki en önemli adımlardan biridir. $\mathrm{Bu}$ amaçla İzmir ili genelinde yapılan survey ve toplama çalışmaları sırasında çok sayıda lokal endemik taksonun populasyon durumu arazide gözlemlenmiş ve sayılmıştır. Bazı taksonların tehlike kategorilerinin, proje çalışmaları sırasında yapılan arazi gözlemleri ve takson birey sayımları ile yakın zamanda tamamlanan bilimsel çalışmalar (İzmir Biyoçeşitlilik Envanter Projesi vb.) doğrultusunda güncellenmeleri önerilmektedir (Çizelge 2).
Ekim ve ark. (2000) ve Anonymous, (2018b)'a göre "Yetersiz Veri" (DD) kategorisinde bulunan 3 hedef türe ulaşılmıştır:

Pilularia minuta Durieu ex A.Br.: 1866 y1lında Balansa tarafindan İzmir Kadifekale'den toplanan örnekle Türkiye'ye ait ilk kaydı verilmiştir. Daha sonra A.J. Byfield ve R. FiczGerold tarafindan İzmir Çeşme Alaçatı'nın Doğusunda 30 m'den toplanmıştır. $\mathrm{Bu}$ toplamadan sonra bitkiye rastlanılmamıştır. Arazi çalışmalarımız sonucunda bitkiye ulaş1lmıştır (Şenol ve ark., 2016).

Isoetes histrix Bory.: Türkiye Florasında 1854 yılında Balansa tarafından Symrne (İzmir) diye Türkiye'ye ait kaydı verilmiştir. Dünya literatüründe bu bitkiye ait en eski ikinci kayıttır. $\mathrm{Bu}$ toplamadan sonra bitkiye rastlanılmamıştır. Bitki farklı iki lokasyondan toplanılmıştır.

Verbascum smyrnaeum Boiss.: 1844 yllında botanikçi Pierre Edmond Boissier tarafından İzmir'de keşfedilen ve keşfedildikten sonra bir daha izine rastlanılamayan, dünyada sadece İzmir'de varlığı bilinen endemik türümüzdür. Doğa Koruma ve Milli Parklar Genel Müdürlüğü tarafından yaptırılan "İzmir Biyoçeşitlilik Envanter Projesi” (Anonymous, 2018a) kapsamında yapılan ortak arazi çalışmalarında toplanmıştır.

Çizelge 2 Tehdit kategorileri kritik (CR) seviyeye güncellenen bitki listesi.

Table 2. Updated list of plants in critical levels.

\begin{tabular}{|c|c|c|c|}
\hline $\begin{array}{l}\text { Bilimsel adı } \\
\text { Scientific name }\end{array}$ & $\begin{array}{l}\text { Türkçe ad } 1 \\
\text { Turkish name }\end{array}$ & $\begin{array}{l}\text { Tehdit kategorisi } \\
\text { Threat category** }\end{array}$ & $\begin{array}{l}\text { Önerilen tehdit kategorisi } \\
\text { Proposed threat category }\end{array}$ \\
\hline Campanula mugeana Y1ldırım & Müge Çançiçeği & - & CR \\
\hline Campanula leblebici Yıldırım & İzmirçanı & - & $\mathrm{CR}$ \\
\hline Peucedanum guvenianum Y1ldırım \& H.Duman & Efe rezenesi & - & $\mathrm{CR}$ \\
\hline Prangos hulusii Şenol, Yıldırım \& Seçmen & Kılçakşır & - & $\mathrm{CR}$ \\
\hline Scilla siehei (Stapf) Speta & Nif karyıldızı & - & $\mathrm{CR}$ \\
\hline Pilularia minuta Durieu ex A.Br. & Teltırfil & DD & $\mathrm{CR}$ \\
\hline Hieracium tmoleum Hub.-Mor. & Ac1 şahinotu & EN & $\mathrm{CR}$ \\
\hline Salvia smyrnaea Boiss. & Nif şalbası & EN & $\mathrm{CR}$ \\
\hline Scilla luciliae (Boiss.) Speta & Bozdağ sümbülü & EN & $\mathrm{CR}$ \\
\hline Minuartia nifensis McNeill & Nif tistis1 & EN & $\mathrm{CR}$ \\
\hline Gentiana lutea subsp. lutea L. & Sar1 Afat & EN & $\mathrm{CR}$ \\
\hline Campanula teucrioides Boiss. & Bozdağ çanı & VU & $\mathrm{CR}$ \\
\hline Asperula daphneola O.schwarz & Yatık belumotu & VU & $\mathrm{CR}$ \\
\hline Rumex tmoleus Boiss. & Özge labada & VU & $\mathrm{CR}$ \\
\hline Jasione supina subsp. tmolea (Stoj.) Damboldt & Bozdağ gökçesi & VU & $\mathrm{CR}$ \\
\hline $\begin{array}{l}\text { Jurinea cadmea subsp. nifensis Yıldırım \& } \\
\text { Şenol }\end{array}$ & Bodurgöbek & VU & $\mathrm{CR}$ \\
\hline Sideritis tmolea P.H.Davis & Sivri çay & $\mathrm{CD}$ & $\mathrm{CR}$ \\
\hline Linum tmoleum Boiss. & Mavi keten & NT & $\mathrm{CR}$ \\
\hline Verbascum smyrnaeum Boiss. & İzmir sığırkuyruğu & DD & $\mathrm{CR}$ \\
\hline Isoetes histrix Bory. & Çimeğreltisi & $\mathrm{DD}$ & $\mathrm{CR}$ \\
\hline
\end{tabular}


Yapılan arazi çalışmaları neticesinde üç bitki türünün de çok dar bir alanda yayılış gösterdiği ve habitatlarının yoğun bir tahribata uğradığı tespit edilmiştir. Arazi çalışmalarındaki populasyon ve arazi gözlemleri ve hocalarımızın bu türler üzerine yürüttükleri proje ve tez verilerine dayanarak, veri yetersiz (DD) kategorisinde bulunan türlerin tehlike kategorisinin kritik düzeyde tehlikede (CR) olarak kayda geçmesi gerekmektedir. Sadece bir ya da iki lokaliteden toplanan türlerin habitatları üzerinde, türleri doğadan yok edecek ölçüde antropojenik tahribat (kentleşme, havaalanı yapımı, baraj ve yol inşaatı, tarla açma, yangın vb.) vardır.

Campanula mugeana Yıldırım: Yıldırım (2013) tarafindan bilim dünyasına tanıtılan yeni türdür (Şekil 3). Mahmut Dağı'nda zirve civarında çok küçük alanda yayılış gösteren lokal endemiktir. Habitatı aşırı otlatma ve rüzgar enerji santralleri (RES) ile ciddi tehdit altındadır.

Campanula leblebici Yıldırım: Yıldırım (2018) tarafindan bilim dünyasına tanıtılan Çaldede (Çıplak) Dağı'nda zirve civarında çok küçük alanda yay1lıs gösteren lokal endemik bir türdür. Habitatı aşırı otlatma ve piknik faaliyetleri nedeni ile ciddi tehdit altındadır.

Prangos hulusii Şenol, Yıldırım \& Seçmen: Bozdağ'da Şenol ve ark. (2011) tarafindan bulunan lokal endemik yeni bir türdür. Çok dar bir alanda yayılış gösteren yeni tür üzerinde Bozdağ ve çevresindeki antropojenik tahribat yoğun olarak hissedilmektedir.

Peucedanum guvenianum Yıldırım \& $\mathbf{H}$. Duman: Yıldırım ve Duman (2017) tarafindan bilim dünyasına tanıtılmış bir lokal endemiktir (Şekil 4). Gümüldür, Tahtalı Barajı civarında maki içi ve yol kenarında yayılış gösteren, birey sayısı çok az olan nokta endemik bir türdür.

Campanula teucrioides ve Jasione supina subsp. tmolea: Bozdağ'a özgü lokal endemik iki türdür (Şekil 5 ve 6) Bozdağ'da aşırı otlatma, yanlış ağaçlandırma, turizm faliyetleri, yol açma çalışmaları nedeniyle çok ciddi habitat tahribatına maruz kalmaktadır. Eroğlu(2011) yaptığı yüksek lisans tezinde türlerin birey sayılarının Campanula teucrioides için 3804 ve Jasione supina subsp. tmolea için 4296 olarak belirlemiştir. Aynı zamanda her iki tür için tehlike kategorilerinin CR'ye yükseltilmesi gerekliliğini vurgulamıştır.

Hieracium tmoleum, Linum tmoleum, Sideritis tmolea, Rumex tmoleus ve Scilla luciliae: İsimlerini Bozdağ'ın mitolojik ismi olan Tmolos'tan alan bu türler dağa özgü lokal endemiktir (Şekil 7-10). Birey sayıları az, çok küçük bir alanda yayılış gösterirler. Bozdağ'da yapılan ağaçlandırma çalışmaları nedeniyle çok ciddi alan tahribatına uğramışlardır. Ayrıca Bozdağ'da yapılan kayak merkezi nedeniyle çok yoğun bir habitat kaybına uğramışlardır. Habitat alanları büyük oranda azalmıştır. Sideritis tmolea, genelde yerel halk tarafindan bitki çayı olarak kullanılmak üzere toplanmaktadır (Şenol, 2012). Toplanan bitkilerin bir kismı halkın kendi ihtiyaçları doğrultusunda kullanılırken bir kısmı da ekonomik nedenlerle satılmaktadır.

Salvia smyrnaea: Yapılan yüksek lisans tez çalışmasında, Salvia smyrnea'nın Türkiye Florasında'ki lokalitelerinin İzmir ve Aydın illerinde verilmiş olmasına rağmen bu türün sadece İzmir ili sınırlarında bulunan Nif Dağı'nda yayılış gösterdiğini ortaya koymuştur (Subaş1, 2010). Salvia smyrnaea dünyada sadece İzmir Nif dağında yetişen endemik bir adaçayı türüdür (Şekil 13). Eğer bu populasyonu da korunmaz ise yok olma tehlikesiyle karşı karşıyadır.

Gentiana lutea subsp. lutea: Bitkinin tıbbi ve süs bitkisi olma özelliği taşımasından dolayı aşırı toplamaya maruz kalmaktadır (Şekil 11). En etkili tıbbi özelliğinin köklerinde olması nedeniyle bitkinin üremesine izin vermeden kökleriyle sökülmektedir. $\mathrm{Bu}$ durum bitkinin lokal düzeyde populasyonunda ciddi azalmalara neden olmaktadır.

Asperula daphneola: Nif Dağı zirvesinde yayılış gösteren ve Mahmut Dağı'nda da küçük bir populasyonu bilinen türdür. Aşırı otlatma ve yol genişletme çalışmaları habitat tahribatına neden olmaktadir.

Minuartia nifensis: Sadece Nif Dağı zirvesinde yayılış gösteren bir türdür (Şekil 12). Aşırı otlatma ve yol genişletme çalışmaları habitat tahribatına neden olmaktadir. 
Scilla siehei ve Jurinea cadmea subsp. nifensis: Nif Dağında dar bir alanda yayılış gösteren ve

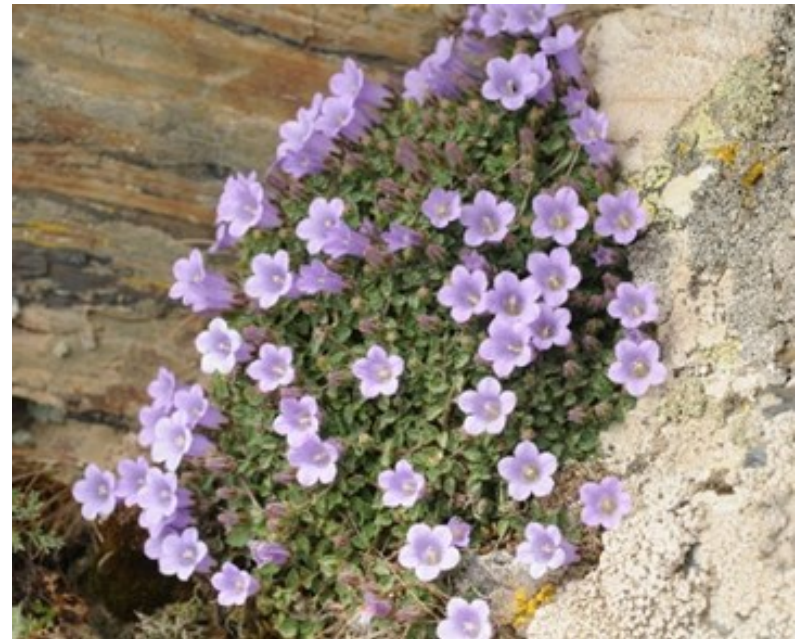

Şekil 3 Campanula mugeana (Foto H. YILDIRIM)

Figure 3. Campanula mugeana (Photo by H. YILDIRIM)

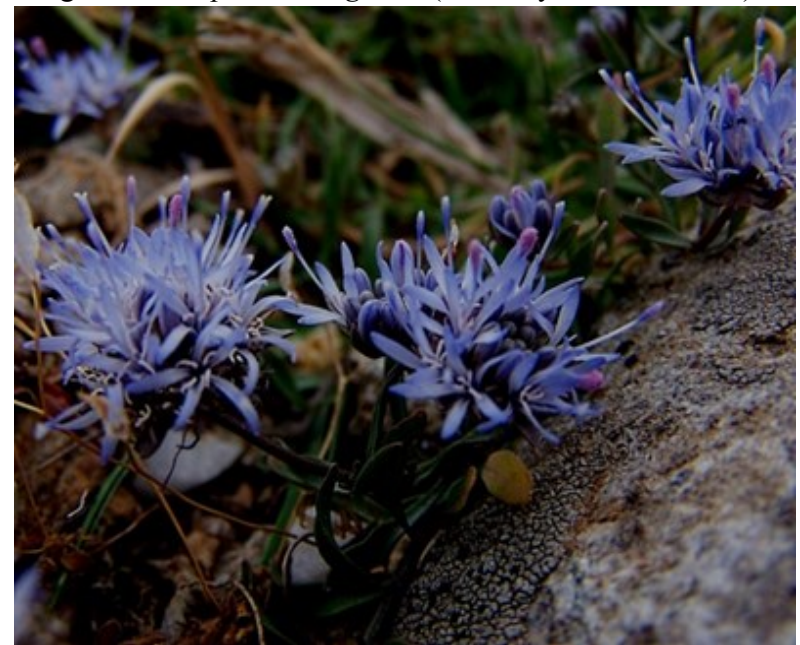

Şekil 5. Jasione supina subsp. tmolea (Foto V. EROĞLU) Figure 5.Jasione supina subsp. tmolea (Photo V. EROĞLU) insan kaynaklı yoğun tahribat altında olan endemik iki türdür.

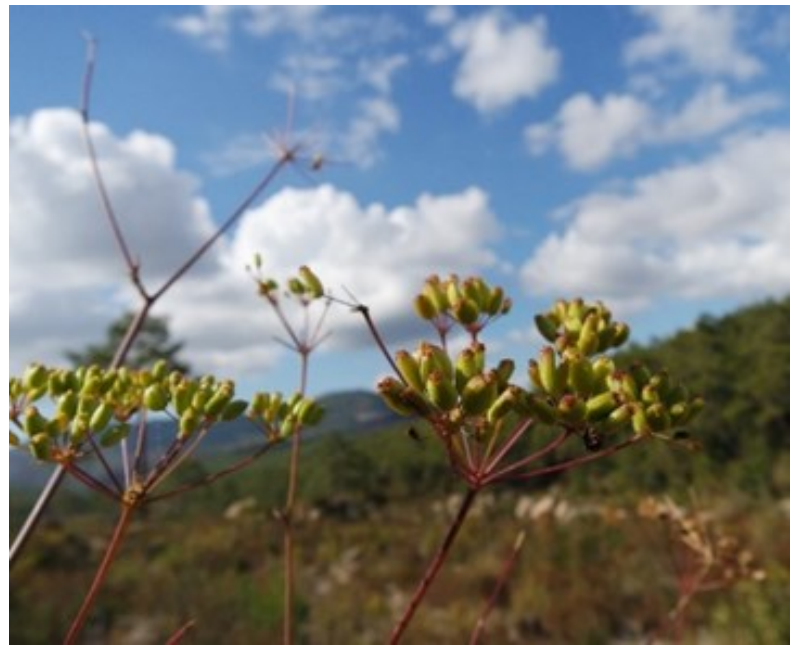

Şekil 4. Peucedanum guvenianum (Foto H. YILDIRIM) Figure4.Peucedanum guvenianum (Photo by H. YILDIRIM)

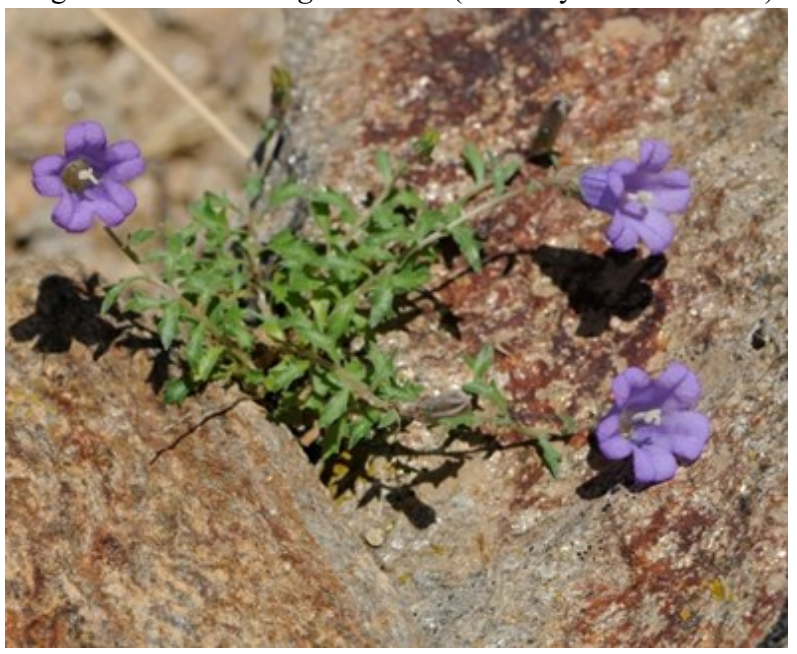

Şekil 6. Campanula teucrioides (Foto S. G. ŞENOL)

Figure 6. Campanula teucrioides (Photo by S. G. ŞENOL) 


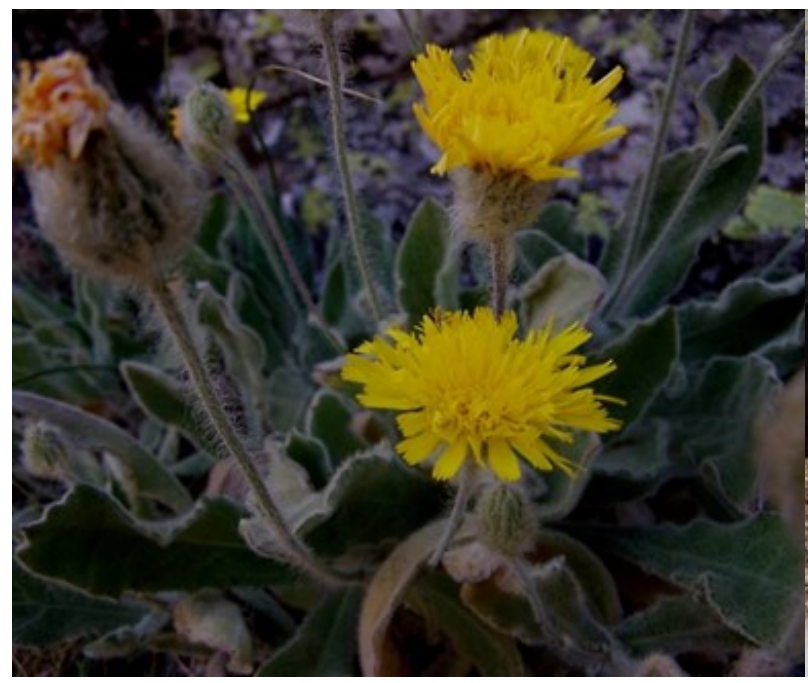

Şekil 7 Hieracium tmoleum (Foto S. G. ŞENOL)

Figure 7. Hieracium tmoleum (Photo by S. G. ŞENOL)

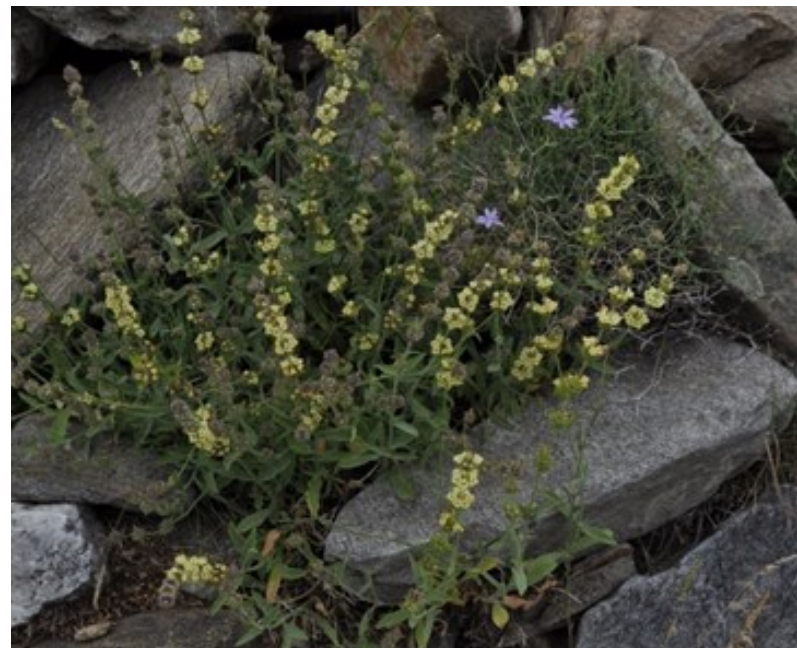

Şekil 9. Sideritis tmolea (Foto S. G. ŞENOL)

Figure 9. Sideritis tmolea Photo by S. G. ŞENOL)

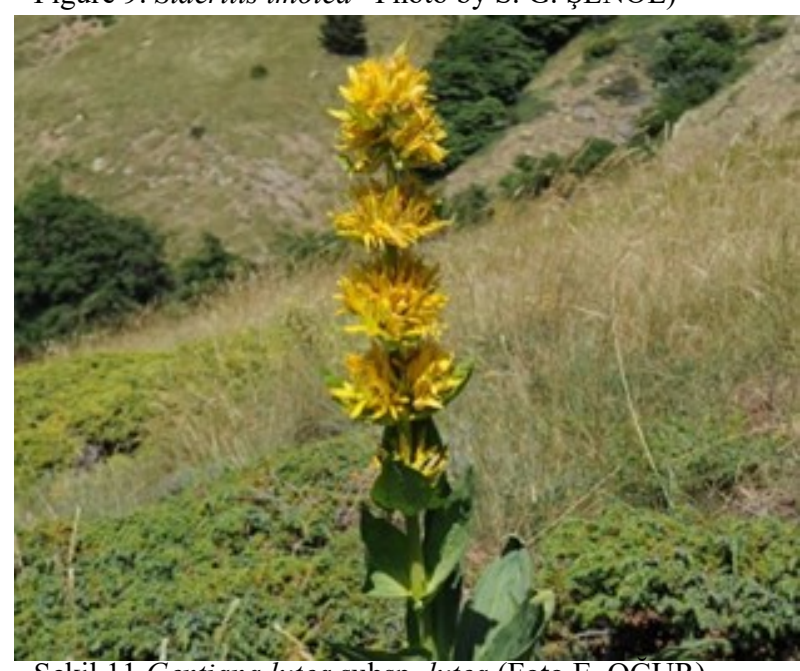

Sekil 11 Gentiana lutea subsp. lutea (Foto E. OGUR)

Figure11. Gentiana lutea subsp. lutea (Photo by E. OĞUR)

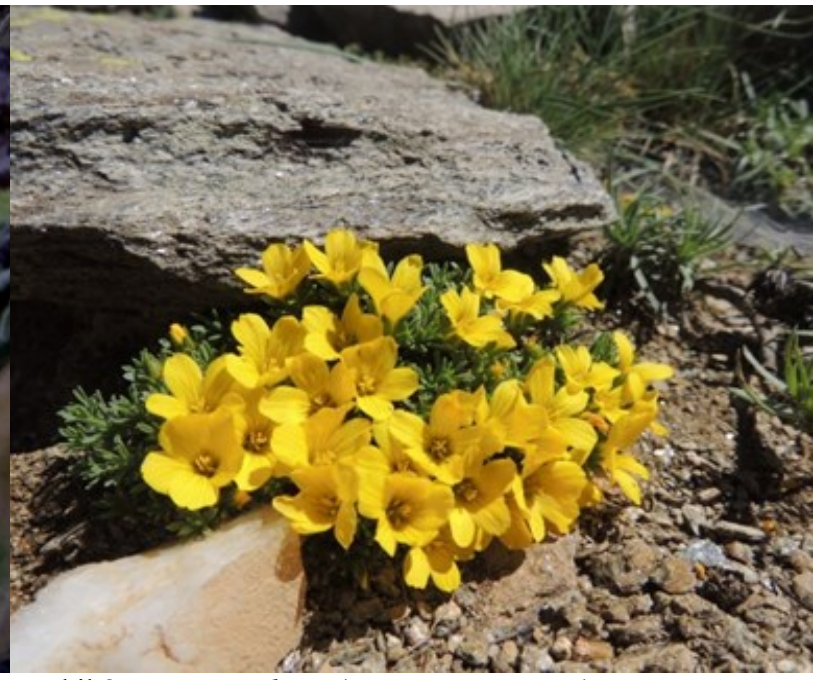

Sekil 8. Linum tmoleum (Foto S. G. SENOL)

Figure 8. Linum tmoleum (Photo by S. G. ŞENOL)

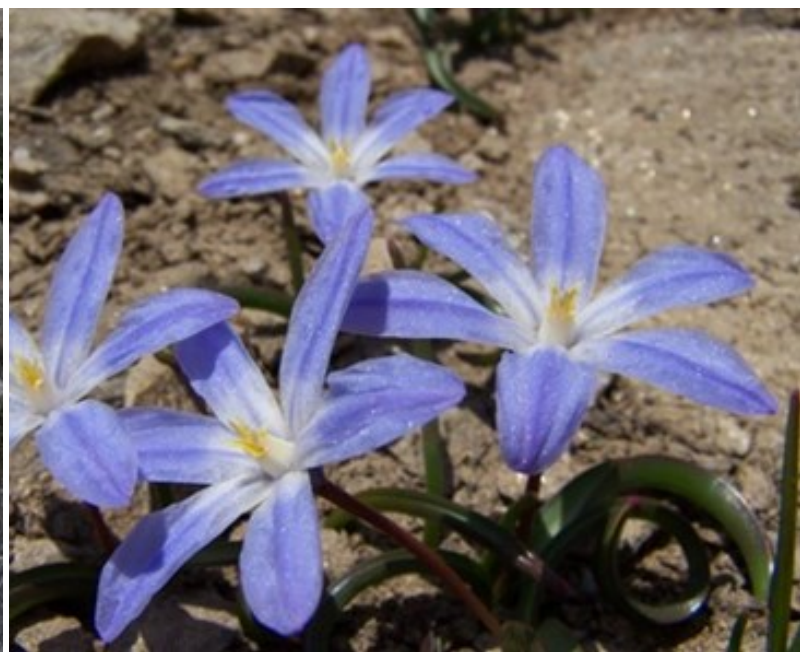

Şekil 10 Scilla luciliae (Foto H. YILDIRIM)

Figure 10. Scilla luciliae (Photo by H.YILDIRIM)

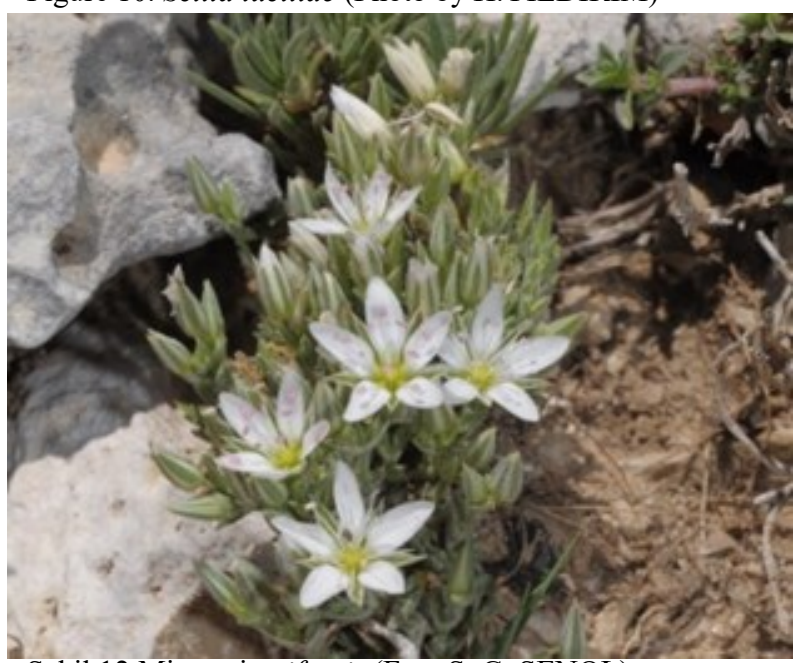

Şekil 12 Minuartia nifensis (Foto S. G. ŞENOL)

Figure 12. Minuartia nifensis (Photo by S. G. ŞENOL) 


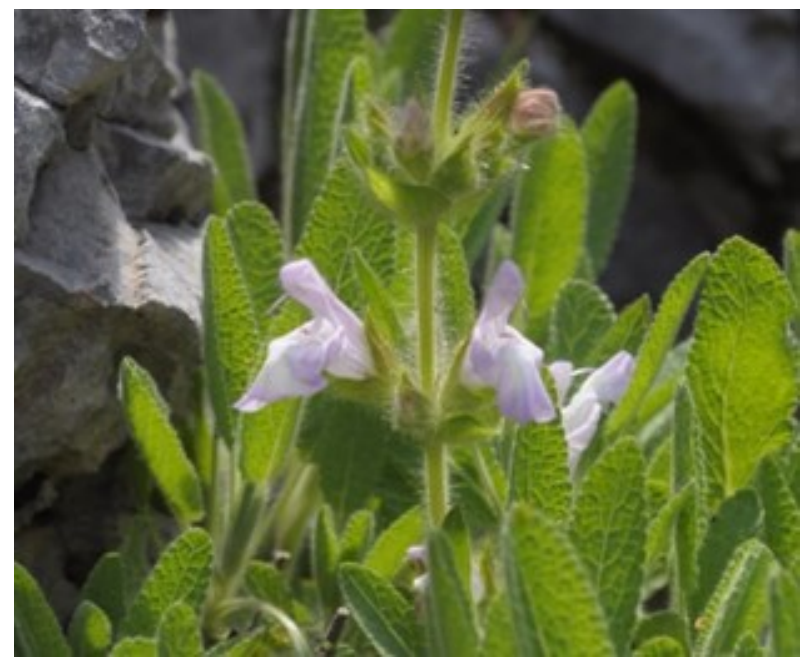

Şekil 13. Salvia smyrnaea (Foto S. G. ŞENOL)

Figure 13. Salvia smyrnaea (Photo by S. G. ŞENOL)

\section{SONUÇ ve ÖNERILER}

Ülkemizin üçünçü büyük kenti olan İzmir, insanlık tarihi ile beraber gelişen yerleşim alanları ve antik kentlerinin yanı sıra birçok endemik ve nadir bitkiye ev sahipliği yapan doğal güzellikleriyle de tanınmış güzide illerimizden biridir.

İzmir'de yetişen, başta endemik ve nadir bitkiler olmak üzere endemik olmayan bitkiler de çeşitli biyotik faktörlerin baskısı altında olup, neslini devam ettirebilme konusunda zorluklarla karşılaşmaktadır. Endemik bitkiler bir ülkenin biyolojik zenginliklerinin başında gelmektedir. $\mathrm{Bu}$ bakımdan endemik bitkilerimizi iyi tanımak ve yok olma tehlikesine karşı koruma tedbirleri almak nesillerinin devamı için çok önemlidir. İşte bu nedenlerden dolayı bu çalışma ortaya çıkmış ve öncelikli hedefi, bölgedeki bitkilerin acilen tespit edilerek ex situ koruma altına alınması ve diğer tamamlayıcı koruma stratejilerinin geliştirilmesi olarak belirlenmiştir.

İzmir ilinde 2014-2018 tarihleri arasında yapılan arazi çalışmalarıyla 115 tanesi endemik, 48 tanesi tip örneği Türkiye olan, 13 tanesi nadir ve 12 tanesi de IUCN (2012)'ye göre tehdit kategorisinde olan 188 taksonun herbaryum örneği alınmıştır. Bu türlerden, 1 takson EW (Doğada Tükenmiş), 6 takson CR (Kritik), 19 takson EN (Tehlikede), 36 takson VU (Duyarl1), 9 CD (Korumaya Tabi), 50 takson LC (Düşük Riskli), 14 takson NT (Tehdite
Yakın) ve 3 takson "DD" (Veri Yetersiz) kategorisindedir (Çizelge 1).

Ayrıca, yapılan çalışmalar sonunda 60 tanesi endemik, 7 tanesi tip örneği Türkiye olan, 8 tanesi nadir olmak üzere 75 taksonun tohum örneği toplanmışır. Tohumların, 6 taksonu CR (Kritik), 8 taksonu EN (Tehlikede), 14 taksonu VU (Duyarl1), 3 taksonu CD (Korumaya Tabi), 18 taksonu LC (Düşük Riskli), 7 taksonu NT (Tehdite Yakın) ve 1 taksonu "DD" (Veri Yetersiz) kategorisindedir (Çizelge 1).

Arazi çalışmaları sırasında belirlenen hedef türlerden mümkün olduğu kadar fazla taksona ulaşarak herbaryum ve tohumlarının toplanılması hedeflenmiştir. Hedef türlerin hemen hemen tüm herbaryumlarına ulaşılırken tohum toplama konusunda istenilen hedeflere ulaşılamamıştır. Bitkilerin tespit edilerek herbaryumları alındıktan sonra tohum örneklerinin alınamamasının nedenleri bu bitkilerin habitatlarının yol yapımı, tarla açma, aşırı otlatma, turizm ve RES çalışmaları gibi baskı altında olmasından kaynaklanmıştır. $\mathrm{Bu}$ nedenlerden dolayı bitkinin tohum bağlama döneminde belirtilen lokalitelere gidildiğinde tohum bulunma olasılığ azalmıştır.

Araştırma alanı ve çevresinin üzerindeki insan kaynaklı olumsuz etkilerinin başlıcaları ve hangi ÖBA'larını etkiledikleri aşağıda özetlenmiştir.

Yapılaşma: Özellikle son yıllarda ülkemizde hızlı bir şekilde gelişme gösteren şehirleşme çalışma 
alanında da bitki örtüsü üzerinde tehlike yaratmaktadır. Şehirmerkezinin genişlemesine parelel olarak ormanlık alanların yoğun olduğu alanlarda yapılaşma bariz bir şekilde etkisini göstermektedir. Bu durum bitki örtüsü ve endemik ya da dar yayıllışı bitkiler üzerinde olumsuz etkiler yaratmaktadir.

Tarım alanlarının açılması: Ülkemizde 1950'li yıllardan sonra tarımda makineleşmeye gidilmesi ve kontrolsüz artan nüfusa yeterli besin sağlayabilmek için çalışma alanımızın eğimi az, kayalık kesimleri arasındaki hafif taşlı derin topraklı organik maddece zengin habitatlar tarım arazisine dönüştürülmektedir. Söz konusu tahribat doğal vejetasyonu ortadan kaldırması şeklinde daha tehlikeli boyutta sürmektedir. Ayrıca endemik ve nadir tür bakımından zengin olan bölgede makilik ve ormanlık alanların tarla haline dönüştürülmesi, bu türlerin yok olması gibi çok ciddi bir sorun yaratmaktadır. Tarım alanlarının açılması en fazla verimli topraklara sahip ÖdemişBozdağ, Tire, Bayındır, Torbalı, Menemen, Bergama ovalarında floristik kompozisyon kaybına neden olmaktadır.

Tarımsal zararlılarla mücadele: Tarımsal alanların bilinçsiz şekilde artmasının yanı sıra bilinçsiz bir şekilde tarım zararlıları ile mücadele edilmektedir. Zirai alanlarda kullanılan pestisitler bitki ve hayvan türleri üzerinde zararlı etkiler oluşturmaktadır. Halkın deyimiyle yabancı otlar için kullanılan bu ilaçlar yabancı otlar ile birlikte endemik ve nadir bitkilere zarar görmektedir.

Hayvancılık ve aşırı otlatma: Bölgede mera gibi alanların çok az olması ve mera olarak kullanılması gereken alanların tarıma açılması nedeniyle otlatma yeri olarak doğal bitki örtüsü kullanılmaktadır. Hayvancılık ve aşırı otlatma baskısının en çok görüldüğü yerler yüksek oranda endemik ve nadir bitkileri barındıran Bozdağ, Nif Dağı, Mahmut Dağı, Karaburun Akdağ, Güme Dağ1 gibi önemli bitki alanlarıdır.

Halkın ticari ya da kendi kullanımı amacı ile doğadan toplamalar: Bilindiği üzere insanoğlunun tarihsel süreci boyunca bazı bitkiler çeşitli amaçlarla (tıbbi, baharat, süs v.b.) doğal ortamlarından toplanmıştır. Genelde yerel halk tarafından toplanan bitkilerin bir kısmı kendi ihtiyaçları doğrultusunda kullanılırken bir kısmı da ekonomik nedenlerle satılmaktadır. Bu bitkilerin bir kısmı endemik bir kısmı da geofittir. Ülkemizin de taraf olduğu Bern ve CITES sözleşmelerinde orkide türlerinin, kesin olarak koruma altına alınan flora türleri ve doğadan toplanmak suretiyle ihraç edilmesi yasak olan çiçek soğanları grubunda yer almasına rağmen süs bitkisi olarak kullanılmak ve salep yapımı amaciyla yumrularının toplanması yoğun bir şekilde devam etmektedir. Ekonomik getiri için toplanan bu tür bitkilerin populasyonlar azalmış hatta yok olma tehlikesiyle karşı karşıya kalmıştır.

Rüzgar enerjisi santralleri: Büyük habitat ve vejetasyon kayıplarına neden olduğu için sadece endemik ve nadir bitkiler üzerinde değil genel floristik yapı üzerine çok büyük tehdit unsuru oluşturmaktadır. Aydın Dağları, Mahmut Dağı, Çeşme-Alaçatı arası ve Karaburun-Akdağ en fazla etkilenen alanlardir.

Orman yangınları İzmir'de hemen hemen her y1 çıkmakta ve bölgedeki biyoçeşitlilikte çok büyük tahribata neden olmaktadır. Bornova, Menderes, Gümüldür, Karaburun, Çeşme ve Foça gibi turistik ve büyük yerleşim alanlarının olduğu bölgelerde orman yangınları sıkça görülmektedir.

Bozdağ ve çevresini "Zümrüt Yeşili Dağlara" dönüştürme projesi kapsamında yapılan yanlış ağaçlandırma politikaları özellikle Bozdă̆'da birçok lokal endemik ve nadir takson üzerinde tahribata neden olmuştur. Özellikle CR kategorisinde ve diğer kategorilerden birçok lokal endemiğin bulunduğu Bozdağ insan müdahalesine açık bir konumdadır.

İzmir ilinin genelinde yaptığımız bu çalışmada endemik ve nadir takson sayıs bakımından en zengin alanların Bozdağ, Nif Dağı, Mahmut Dağı ve Aydın Dağları serileri olduğu görülmüştür. Oldukça hassas olan bu habitatların korunması ve izlenmesi gereken en önemli alanlar olduğunu düşünülmektedir. Özellikle belirtilen alanlar için bu proje çalışmaları ve daha önce yapılan çalışmalarda önerilen koruma stratejilerin uygulanması son derece önemlidir.

Ülkemizde bitki çeşitliliğini ortaya koyma adına son yıllarda çok sayıda bilimsel araştırmalar 
yapılmıştır. Çoğunluğu üniversitelerce yapılan çalışmalar daha çok floristik araştırmalarla sınırlı kalmıştır. Bir bitkinin ismini öğrenmek onu tanımak için ilk şarttır. Ancak onu korumak, yaşatmak, gelecek nesillere aktarmak ve ekonomiye kazandırmak için yeterli değildir. $\mathrm{Bu}$ nedenle bitkilerin yayılışları, populasyon durumları, ekolojik istekleri, çimlenme fizyolojisi, agronomik özellikleri gibi yaşamının devamı ile doğrudan ilgili birçok konu hakkında ayrıntılı bilgiler gereklidir.

Biyolojik çeşitliliğin ve genetik kaynakların bilinmesi korunması ve sürdürülebilir yönetimi, önemi giderek artan stratejik bir konu olarak dünya gündeminde yer almaktadır. Bu çalışma kapsamında toplanan tohum materyalini sadece $e x$-situ korumaya almakla yetinilmeyecektir. Özellikle endemik, nadir ve nesli tükenmekte olan türlerin etkin biçimde korunmasındaki temel noktalardan biri de, bu türlerin çoğaltılmasına yönelik çalışmaların yapılmasıdır. $\mathrm{Bu}$ amaçla bu türler üzerinde, bitkilerin kullanım alanlarına (gıda, tıbbi, süs vb.) göre ETAE bünyesinde bulunan birimlerce koruma ve ekonomiye kazandırma adına çoğaltma ve kültüre alma çalışmaları yürütülecektir. Özellikle CR seviyesinde tehdit altında olan endemik bitkilerin, doku kültüründe in vitro koşullar altında

\section{LITTERATÜR LISSTESI}

Anonymous, 2001. IUCN Red List Categories: Species Survival Commision. Version 3.1, Gland, Switzerland.

Anonymous, 2003. Guidelines for Application of IUCN Red List Criteria at Regional Levels, Version 3.0. Gland, Switzerland and Cambridge, UK: IUCN.

Anonymous, 2009. Appendices I, II and III http://www.cites.org/eng/app/appendices.shtml. (Erişim Tarihi:25.11.2015).

Anonymous, 2012. IUCN Red List categories and criteria, version 3.1, second edition (Turkish version), ISBN 978-2-8317-1435-6. Gland and Cambridge.

Anonymous, 2013a. The Plant List (a working list of all plant species). http://www.theplantlist.org/. (Erişim tarihi 01/10/2015).

Anonymous, 2013b. Ulusal Dijital Herbaryum Veri Taban1. http://herbaryum.tagem.gov.tr/. (Erişim tarihi 31/12/ 2018)

Anonymous, 2018a. “İzmir İli’nin Karasal ve İç Su Ekosistemleri Biyolojik Çeşitlilik Envanter ve İzleme kriyoprezervasyon yöntemi kullanarak muhafaza çalışmaları yapılacaktır. Ayrıca, fizyolojik, moleküler, genetik, doku kültürü ve agronomi çalışmaları bu türler üzerinde yoğunlaştırılacaktır.

Biyoçeşitliliğin korunması ve sürdürülebilir kullanımının ulusal düzeyde tüm paydaşlarla bütünleştirilmesi gereklidir. $\mathrm{Bu}$ nedenle botanikçiler, ziraat mühendisleri ve orman mühendislerinin birlikte, koordineli olarak koruma çalışmalarına katılmaları ayrı bir önem taşımaktadır.

\section{TEŞEKKÜR}

$\mathrm{Bu}$ çalışma, Tarımsal Araştırmalar ve Politikalar Genel Müdürlügü (TAGEM) tarafindan desteklenmiş, T.C. Ege Tarımsal Araştırma Enstitüsü Müdürlüğü bünyesinde yürütülmüştür. Projenin, gerek arazi çalışmalarında gerekse herbaryum örneklerinin teşhişlerinde katkıda bulunan Ege Üniversitesi Fen Fakültesi Biyoloji Bölümü öğretim üyeleri Doç. Dr. Serdar Gökhan ŞENOL, Doç. Dr. Hasan YILDIRIM Dr. Volkan EROĞLU ve Nejdet BOZKURT'a teșekkür ederim. Ayrıca, Lerzan AYKAS, Dr. Neșe ADANACIOĞLU ve Dr. Ümmügülsün YILDIZ'a projedeki yardımlarından dolayı teşekkür ederim.

İşi sonuç raporu", T.C. Çevre ve Orman Bakanlığı, Ankara.

Anonymous, 2018b. Tehdit Altındaki Bitki Türleri Listesi. $\mathrm{http} / / / \mathrm{www}$. tehditaltindabitkiler.org.tr/v2/. (Erişim tarihi 01/11/2018).

Anonymous, 2018c. Uluslararası Bitki Adları İndeksi. http://www.ipni.org. The Royal Botanic Gardens, Kew, Harvard University (Erişim tarihi: 10 Aralık 2018).

Boissier, E. 1979-1984. Flora Orientalis, IV-V, Basel-GenovaLyon.

Çepel, N. 2003. Ekolojik Sorunlar ve Çözümleri. Tübitak Popular Bilim Kitaplar 180. Aydoğdu Matbaas1, Ankara,

Davis P. H. 1965 - 1985. "Flora of Turkey and East Aegean Islands, Vol I-IX, Edinburg Univ. Press UK.

Davis, P. H., R. R. Mill, and K. Tan. 1988. Flora of Turkey and The East Eagean Islands. Suplement I. Edinburg Universty Press, Edinburg.

Demirsoy, A. 1996. Genel ve Türkiye Zoocoğrafyası. Meteksan AȘ. Ankara. 
Eken, G., M. Bozdoğan, S. İsfendiyaroğlu, D.T. Kılıç ve Y. Lise. 2006. Türkiye'nin Önemli Doğa Alanları, Doğa Derneği, Ankara.

Ekim, T., M. Koyuncu, M. Vural, H. Duman, Z. Aytaç ve N. Adıgüzel. 2000. Türkiye Bitkileri Kırmızı Kitabı. Türkiye Tabiatını Koruma Derneği. Ankara.

Ellis, R. H., T. D. Hong, and E. H. Roberts. 1985. Handbook of Seed Technology for Gene Banks, Volume I: Principles and Methodology. IBPGR, Rome

Eroğlu, V. 2011. Campanula teucroides Boiss. ve Jasione supina subsp. tmolea Damboltd tozlaşma biyolojisi Yüksek Lisans Tezi. Ege Üni. Fen Bilimleri Enstitüsü. Bornova-İzmir

Güner, A., N. Özhatay, T. Ekim, and H. K. C. Başer. 2000. Flora of Turkey and East Aegean Islands. Edinburgh University Press. Supplement 2 Vol.11.Edinburgh.

Güner, A., S. Aslan, T. Ekim, M. Vural ve M. T. Babaç. 2012. Türkiye Bitkileri Listesi (Damarlı Bitkiler). Nezahat Gökyiğit Botanik Bahçesi ve Flora Araştırmaları Derneği Yayını. İstanbul.

Hawkes, J. G. 1980. Crop Genetic Resources Field Collection Manuel. I.B.P.G.R and Eucarpia. Pudoc, Wageningen.

Heywood V. H., and G. T. Tutin. 1963-1980. Flora Europaea. Vol. I-V. Cambridge University Press, Cambridge.

Karagöz A., N. Zencirci, A. Tan, T. Taşkın, H. Köksel, M Sürek, C. Toker ve K. Özbek. 2010. Bitki Genetik Kaynaklarının Korunması ve Kullanımı. Türkiye Ziraat Mühendisliği VII. Teknik Kongresi. 11-15 Ocak 2010. Bildiriler Kitab1 - I: 155-177

Özhatay, N., and Ş. Kültür. 2006. Check-list of additional taxa to the supplement flora of Turkey III. Turk J. Bot. 30 (4): 281-316.

Özhatay, N. and Ş. Kültür, S. Aslan. 2009. Check-list of additional taxa to the Supplement Flora of Turkey IV. Turk J. Bot 33: 191-226.

Özhatay, N., Ş. Kültür and S. Aslan. 2011. Check-list of additional taxa to the Supplement Flora of Turkey V. Turk J Bot 35: 1-36.

Özhatay, N., Ş. Kültür and B. Gürdal. 2013. Check-List of Additional Taxa to the Supplement Flora of Turkey VI. Istanbul Ecz. Fak. Dergisi 43(1): 33-82.

Özhatay, N., S. Kültür and B. Gürdal. 2015. Check-list of additional taxa to the supplement flora of Turkey VII. Istanbul J Pharm. 45 (1): 61-86.

Özhatay, N., Ş. Kültür and B. Gürdal. 2017. Check-list of additional taxa to the supplement flora of Turkey VIII. Istanbul J Pharm. 47 (1): 31-46

Rechinger, K. H. 1943. Flora Aegaea: Flora der Inseln und Halbinseln des Ägäischin Meeres. Ôsterr. Akademie der Wissenschaften in Wien, Denkschriften 105. Bd.1. vii-924.

Seçmen, Ö., Y. Gemici, G. Görk, L. Bekat ve E. Leblebici. 2008. Tohumlu Bitkiler Sistematiği, Ege Üniversitesi Fen Fakültesi Kitapları Serisi No:116, İzmir.

Strid, A., and K. Tan. 1991. Mountain Flora Of Greece. Edinburg University Press. Edinburg.

Subaşı, Ü. 2010. Salvia smyrnaea Boiss. üzerinde otoekolojik incelemeler. (Yüksek Lisans Tezi), Ege Üniversitesi Fen Bilimleri Enstitüsü Bornova-İzmir.

Şenol, S. G., H. Yıldırım, and Ö. Seçmen. 2011. Prangos hulusii sp. nov. (Apiaceae) from West Anatolia, Turkey. Nordic J. of Botany 29 (4): 402-409.

Şenol, S. G., 2012. İzmir-Ödemiş Bozdağ a özgü endemik bitkilerin koruma biyolojisi. TÜBİTAK, 108T851 nolu Araştırma Projesi.

Şenol, S. G., E. Oğur, D. Bozyel, N. B. Pelit, and G. E. Arslan. 2016. Morphological, anatomical, ecological features of Pilularia minuta and its distribution of Turkey. Symposium on Euroasian Biodiversity (SEAB) Antalya.

Tan, A. 2000. Biodiversity conservation. Ex situ and İn situ conservation: A case in Turkey. In: K. Watanabe and A. Komamine (Eds.). Chalenge of Plant and Agricultural Sciences to the crisis of biosphere on the Earth in the 21st Century. Eurekah, Texas.

Tan, A. ve T. Taşkın. 2001. Herbaryum Hazırlama Teknikleri. TAYEK/TYUAP. 4-6 Eylül 2001. Ege Tarımsal Araştırma Enstitüsü Yayınları. 103: 1-6. Menemen, İzmir.

Tan, A. 2010a. Türkiye bitki genetik kaynakları ve muhafazası. Anadolu J. of AARI. 20 (1): 7-25.

Tan, A. 2010b. Türkiye Gida ve Tarim Bitki Genetik Kaynaklarinin Durumu. Gıda Ve Tarım Için Bitki Kaynaklarının Muhafazası Ve Sürdürülebilir Kullanımına İlişkin Türkiye İkinci Ülke Raporu. ETAE Yayın No: 141. Meta Basım. Bornova ISBN 978-975-407-292-1.

Tezer, N. M. 2012. İzmir'in ekonomik ve tıbbi değer taşıyan endemik bitkileri. Biyoçeşitlilik sempozyumu bildiri kitab1. s.195-199.

Y1ldırım, H. 2013. Campanula mugeana sp. nov. (Campanulaceae) from western Anatolia, Turkey. Nordic J. of Botany 31 (4) :419-425.

Yıldırım, H., and H. Duman. 2017. Peucedanum guvenianum (Apiaceae), a new species from West Anatolia, Turkey. Turkish Journal of Botany-41: 600-608.

Yildırım, H. 2018. Campanula lebleicii (Campanulaceae), a new chasmophyte species from western Turkey. Phytotaxa 376 (2): 114-122. 